\title{
HIV chemokine receptor inhibitors as novel anti-HIV drugs
}

\author{
Katrien Princen, Dominique Schols* \\ Laboratory of Virology and Chemotherapy, Rega Institute for Medical Research \\ University of Leuven, Minderbroedersstraat 10, B-3000 Leuven, Belgium
}

Available online 6 July 2005

\begin{abstract}
The chemokine receptors CXCR4 and CCR5 are the main coreceptors used by the T-cell-tropic (CXCR4-using, X4) and macrophagetropic (CCR5-using, R5) HIV-1 strains, respectively, for entering their CD4 ${ }^{+}$target cells. In this review, we focus on the function of these chemokine receptors in HIV infection and their role as novel targets for viral inhibition. Besides some modified chemokines with antiviral activity, several low-molecular weight CCR5 and CXCR4 antagonistic compounds have been described with potent antiviral activity. The best CXCR4 antagonists described are the bicyclam derivatives, which consistently block X4 but also R5/X4 viral replication in PBMCs. We believe that chemokine receptor antagonists will become important new antiviral drugs to combat AIDS. Both CXCR4 and CCR5 chemokine receptor inhibitors will be needed in combination and even in combinations of antiviral drugs that also target other aspects of the HIV replication cycle to obtain optimum antiviral therapeutic effects.
\end{abstract}

(C) 2005 Elsevier Ltd. All rights reserved.

Keywords: HIV; Chemokine receptor; Antagonist; CCR5; CXCR4

\section{Introduction}

The human immunodeficiency virus (HIV), that causes acquired immunodeficiency syndrome (AIDS), was first

Abbreviations: AIDS, acquired immune deficiency syndrome; AOP, aminooxypentane; CI, clinical isolate; DC, dendritic cell; DC-SIGN, dendritic cell-specific ICAM-3-grabbing nonintegrin; FDA, Food and Drug Administration; FLIPR, fluorometric imaging plate reader; GCP, granulocyte chemotactic protein; GFP, green fluorescent protein; gp, glycoprotein; GPCR, G protein-coupled receptor; GRK, G protein-coupled receptor kinase; GTP, guanosine triphosphate; HAART, highly active antiretroviral therapy; HIV, human immunodeficiency virus; $\mathrm{HR}$, helical region; $\mathrm{IP}_{3}$, inositol triphosohate; LTNPs, long-term nonprogressors; LTR, long terminal repeat; M/M, monocytes/macrophages; MAPK, mitogen activated protein kinase; MCP, monocyte chemoattractant protein; MDC, macrophage-derived protein; MIP, macrophage inflammatory protein; NNRTIs, non-nucleoside reverse transcriptase inhibitors; NNY, $N$-nonanoyl; NRTIs, nucleoside reverse transcriptase inhibitors; NSI, non-syncytium-inducing; PDI, protein-disulfide isomerase; $\mathrm{PI} 3 \mathrm{~K}$, phosphoinositide 3 kinase; $\mathrm{PIP}_{2}$, phosphatidylinositol 4,5-biphosphate; RANTES, regulated on activation normal T-cell expressed and secreted; RPs, rapid progressors; SDF-1, stromal cell-derived factor-1; SI, syncytium-inducing; TM, transmembrane

* Corresponding author. Tel.: +32 16 337341/337373; fax: +32 16337340 .

E-mail addresses: katrien.princen@rega.kuleuven.ac.be (K. Princen), dominique.schols@rega.kuleuven.ac.be (D. Schols). identified 20 years ago by Barré-Sinousi and colleagues in 1983 [1,2]. Since its discovery as the etiological agent of AIDS, the disease has spread in successive waves in various regions around the world. At present, up to 40 million people are living with HIV/AIDS and already more than 20 million people have been killed by the global HIV/AIDS epidemic (UNAIDS/WHO Report, 2003).

Tremendous efforts are made already to fully understand the pandemic of the virus and in consequence, to develop an effective therapy to control the spread of the virus. This led to the development of about 20 effective antiretroviral drugs approved by the Food and Drug Administration (FDA) for treating HIV-infected individuals. These drugs have been developed to target important and vulnerable steps in the virus replication cycle. The majority of them are reverse transcriptase and protease inhibitors, and a more recently approved drug is an HIV-1 fusion inhibitor [3]. Eventually, due to resistance caused by mutations, virus strains already became insensitive to most of these drugs. To overcome this tremendous problem, researchers started to test combination therapy of these single therapeutics and new derivatives are in development, active against these resistant viruses. In regions were these antiviral drugs are available, they already led to a decline of mortality due to HIV disease (UNAIDS/ 
WHO Report, 2003). Unfortunately, none of these currently approved drugs is able to prevent establishment of HIV-1 infection or eradicate infection. Therefore, there is a constant need for new and improved anti-HIV drugs.

\section{The human immunodeficiency virus: an overview}

HIV is a retrovirus from the lentivirus subfamily. Two major subtypes of HIV, HIV-1 and HIV-2, have been characterized. HIV-1 is the predominant HIV type throughout the world while HIV-2 is mostly found in West Africa [4]. Of HIV-1, two subtypes can be distinguished based on nucleotide sequence relationships, i.e. group $\mathrm{M}$ ('majority') and group $\mathrm{O}$ ('outlier'). In group $\mathrm{M}$, at least ten genetically different subtypes have been identified (from A to J). Group O contains virus strains that are very divergent compared to those of group $M$ [5]. The following part presents more information on the structure and replication cycle of HIV and highlights the different classes of antiretroviral therapeutics investigated.

\subsection{HIV structure}

The mature HIV virion is an icosahedral sphere with a diameter of approximately $100 \mathrm{~nm}[6]$. The outer shell, the viral envelope is a lipid bilayer, from host membrane origin, that embeds host cell proteins and spikes. These spikes consist of two viral envelope proteins (env): an outer protruding cap glycoprotein (gp) 120 and a stem gp41, which are non-covalently attached to each other. These glycoproteins are formed by cleavage of a larger precursor gp160, by a cellular protease. Located within the viral envelope is the matrix, made of an HIV protein called p17, and herein the viral conical core or capsid, which is made of the viral protein $p 24$ (core antigen).

The viral core contains two single strands of HIV RNA and multiple reverse transcriptase molecules $(p 51)$, the nucleocapsid proteins $p 6$ and $p 7$, the protease $p 11$ and the integrase $p 32$.

The HIV genome exists of nine different genes whereof three (gag, pol and env) are common in all retroviruses [6]. Gag is the gene coding for the viral core proteins, pol codes for the viral enzymes reverse trancriptase, integrase and protease and env codes for the envelope glycoproteins. The other genes (tat, rev, vpr, nef, vif and $v p u$ ) are responsible for the organisation of the virus life cycle.

To ensure the effective production of new virions by its host cells the viral genome is flanked at each site by long terminal repeat (LTR) sequences that can bind cellular proteins to activate transcription under control of viral signals.

\subsection{HIV replication cycle}

HIV infection starts with adsorption of a HIV virion to the cell membrane [6,7]. First, the viral envelope protein gp120 binds to the cellular CD4 receptor that is expressed mainly on T-cells and monocyte/macrophages. This binding causes a conformational change in the gp120 uncovering the coreceptor binding site and subsequently the hydrophobic amino-terminal domain of gp41. Binding of the virion to its coreceptor, one of the chemokine receptors CCR5 or CXCR4, is followed by insertion of the N-terminal end of gp41 ('fusion peptide') into the cellular membrane causing fusion of the viral with the cellular membrane which admits virus entry into the target cell (see Section 4.3). Thereafter, the virus is uncoated, and the genetic material of the virus is released into the cell cytoplasm. The single-stranded RNA is immediately transcribed to double-stranded DNA by the viral reverse transcriptase enzyme. This "proviral DNA" then enters the cell nucleus and becomes integrated in the host cell DNA under catalyzation of the viral enzyme integrase. After integration, HIV can persist latently for many years [8-10]. By reactivation of the host cell, transcription from DNA into messenger RNA (mRNA) is started including the inserted viral DNA, which is subsequently translated into viral proteins. After migration of the viral RNA and viral proteins out of the cell nucleus and post-translational modification of viral proteins by the viral enzyme protease, these virus elements assemble at the cell membrane into a new virion. During a process that is called 'budding', the new virion is released from the cell surface using the host cells' surface bilayer to form its outer shell.

\section{Antiviral therapy}

The widespread use of currently approved drugs, reverse transcriptase and protease inhibitors, has already resulted in a significant decrease of mortality of HIV-infected persons in the developed world. Introduction of highly active antiretroviral therapy (HAART), which uses combinations of three or more reverse transcriptase and protease inhibitors, showed already a decrease of viral load to below detectable levels but still cannot eliminate HIV completely in infected individuals. The virus remains in viral reservoirs, from where it rebounds after therapy is stopped [8-10]. Moreover, the efficacy of these products is limited by the emergence of drug-resistant HIV strains [3]. Furthermore, these AIDS-slowing drugs are unaffordable in countries of the less developed world [11]. In addition to the efforts made to improve these currently available drugs to overcome these problems, investigational agents are in development in various classes, each class targeted at another intervention point in the viral life cycle. Table 1 gives an overview of the different classes of inhibitors and the currently available or new potential agents in those distinct classes.

The development of new and improved antiretroviral drugs has to deal with issues of long-term toxicity, oral availability, and drug-resistance and cross-resistance. Besides the well-known reverse transcriptase and protease inhibitors, which are already relatively numerous, another 
Table 1

Overview of HIV chemokine receptor inhibitors

\begin{tabular}{|c|c|c|}
\hline Agent & Characteristics & Reference \\
\hline \multicolumn{3}{|l|}{ Modified chemokines } \\
\hline Met-RANTES & Aminoterminal addition of methionine residue & [102] \\
\hline RANTES(9-68) & Synthetic truncated form of RANTES & {$[100]$} \\
\hline RANTES(3-68) & Processed by CD26; two N-terminal amino acids removed & [98] \\
\hline AOP-RANTES & Aminooxypentane-RANTES & [101] \\
\hline NNY-RANTES & $N$-nonanoyl-RANTES & {$[87]$} \\
\hline Met-SDF-1 & Aminoterminal addition of methionine residue & {$[105]$} \\
\hline AOP-LD78 $\beta$ & Aminooxypentane-LD78 $\beta$ & [104] \\
\hline PSC-RANTES & $\begin{array}{l}\text { Substitution of first three } \mathrm{N} \text {-terminal amino acids for a } \\
\text { nonanoyl group, a thioproline, and a cyclohexylglycine }\end{array}$ & {$[103]$} \\
\hline \multicolumn{3}{|l|}{ CXCR4 antagonists } \\
\hline AMD3100 & Small-molecule bicyclam & {$[114]$} \\
\hline ALX40-4C & 9 D-Amino acid polycationic peptide & {$[124]$} \\
\hline $\mathrm{T} 22$ & 18 Amino acid peptide; polyphemusin & {$[121]$} \\
\hline $\mathrm{T} 140$ & 14 Amino acid peptide & {$[123]$} \\
\hline CGP64222 & 9 Amino acid basic peptide & [128] \\
\hline KRH-1636 & Low molecular weight molecule & {$[130]$} \\
\hline AMD070 & Low molecular weight molecule & {$[131]$} \\
\hline \multicolumn{3}{|l|}{ CCR5/CXCR4 antagonists } \\
\hline AMD3451 & Low molecular weight molecule & {$[132]$} \\
\hline \multicolumn{3}{|l|}{ CCR5 antagonists } \\
\hline TAK-779 & Low molecular weight molecule & {$[133]$} \\
\hline SCH-C (SCH 351125) & Small-molecule oxime-piperidine compound & {$[135]$} \\
\hline SCH-D (SCH 417690) & Derivative of SCH-C & {$[137]$} \\
\hline PRO 140 & Anti-CCR5 mAb & {$[141]$} \\
\hline GW873140 & Spiroketopiperazine-based molecule & {$[144]$} \\
\hline UK-427,857 & Low molecular weight molecule & [140] \\
\hline
\end{tabular}

class of inhibitors, designated entry inhibitors is under investigation, which as their name indicates, inhibit penetration of the HIV virion through the host cell membrane. These entry inhibitors can be subdivided in three different classes, each inhibiting another step of viral entry. The first class of compounds, the adhesion inhibitors, is targeted at the gp120-CD4 binding. Secondly, the coreceptor antagonists inhibit the binding of HIV-1 to the chemokine receptors CCR5 and CXCR4, the major coreceptors for HIV-1. The third class is that of the fusion inhibitors, which bind to different components of gp41, and in this way prevent fusion of the virus with the cellular membrane. The first entry/fusion inhibitor T-20 or enfuvirtide (Fuzeon ${ }^{\mathrm{TM}}$ ) has recently been approved by the FDA. This agent is not bioavailable and one report already showed rapid emergence of clinical resistance to this novel class of compounds [12]. The integrase inhibitors are another new class of antiretroviral compounds that interfere with one or more catalytic functions of the viral integrase enzyme. In addition, also the maturation (assembly) inhibitors are a new class of HIV inhibitors, which prevent assembly of new virus particles.

\section{Chemokine receptors as HIV coreceptors}

Almost a decade ago now, the chemokine receptors CCR5 and CXCR4 were identified as the major coreceptors for HIV-1 entry, besides the cellular CD4 receptor [13-17]. The observation that the natural ligands of these receptors

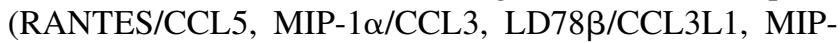
$1 \beta / C C L 4$ SDF-1/CXCL12) and also some specific monoclonal antibodies against certain epitopes of these receptors possess anti-HIV-1 activity, made these chemokine receptors attractive novel targets for future anti-HIV therapy [18]. This idea was further supported by the fact that people with a homozygeous 32 basepair (bp) deletion in the CCR5 gene (CCR5 $\Delta 32 / \Delta 32$ ), that is decoded in a receptor protein that remains intracellular, show a complete normal phenotype and are relatively resistant against HIV-1 infection [19-21].

\subsection{Chemokine receptors}

The migration and activation of leukocytes during normal and inflammatory processes is controlled by chemotactic cytokines or chemokines [22]. Chemokines mediate their biological activities by binding to their specific chemokine receptors. To date, 6 CXC- (CXCR1-6), and 10 CCchemokine receptors (CCR1-10), $1 \mathrm{XC}-$ and $1 \mathrm{CX}_{3} \mathrm{C}$ chemokine receptor are identified [23]. Chemokine receptors are members of the rhodopsin or serpentine receptor superfamily. These are $\mathrm{G}$ protein-coupled seven transmembrane (7TM) receptors (GPCR), containing an acidic extracellular N-terminal domain, 7TM regions and an intracellular cytoplasmatic tail. The $\mathrm{N}$-terminal domain is believed to be essential for ligand binding, whereas the 
C-terminus is important in $\mathrm{G}$ protein activation. The receptors contain $\mathrm{N}$-glycosylation sites in the $\mathrm{N}$-terminal and extracellular regions. The intracellular C-terminus contains several serine and threonine residues, which function as phosphorylation sites, important for desensitization of the receptor. The receptors are typically 340-370 amino acids in length with $25-80 \%$ amino acid homology. Chemokine receptors are expressed on different types of leukocytes.

Some are restricted to certain cells while others are spread over various cell types. Only few are expressed constitutively, mostly their expression is induced by other factors (i.e. interleukines, growth factors, cell activation, etc.). In addition, they are also expressed on non-hematopoietic cells like neurons, astrocytes and endothelial cells [24]. Their distinct expression pattern already suggests that the chemokine system has other functions of chemokines besides their role in leukocyte chemotaxis and inflammation. Most chemokine receptors bind more than one chemokine. However, CC and $\mathrm{CXC}$ receptors have similar primary, secondary and tertiary structures, $\mathrm{CC}$ and $\mathrm{CXC}$ receptors only specifically bind CCand CXC-chemokines, respectively, due to their different quaternary structures [25].

In addition to these specific receptors, other nonsignaling molecules are reported that can bind chemokines. One of them is the Duffy antigen receptor for chemokines (DARC) [26]. This receptor is a 7TM receptor, expressed on erythrocytes and endothelial cells, which is known as determinant of the Duffy blood group. It functions as the receptor for the malarial parasite Plasmodium vivax. It is structurally related to chemokine receptors but in contrast does not support chemokine-induced calcium responses. Other non-signaling receptors described are the CCchemokine receptor D6 [27] and CCX-CKR [28]. Furthermore, negatively charged heparan sulfate proteoglycans (glycosaminoglycans) in the extracellular matrix and on endothelial cells can bind both CC- and CXC-chemokines $[29,30]$. In addition, it is reported that such immobilisation of chemokines on cellular or extracellular matrix is a selective proces, since specific chemokines bind different types of glycosaminoglycans with divergent affinities [31]. Binding of chemokines to glycosaminoglycans induces polymerization of chemokines at a certain site, resulting in higher local chemokine concentrations or gradient formation. This causes migration of leukocytes up to the chemokine gradient and the relevant site of inflammation or disease [32].

\subsection{Identification of chemokine receptors as 'cofactors' for HIV-infection}

In 1984, it was discovered that interaction with CD4 is essential for HIV-1 to enter its host cells [33-35]. However, CD4 alone appeared to be insufficient to permit efficient HIV-1 infection. Two related phenomena led to this conclusion. First, expression of human CD4 on the surface of murine cells did not confer susceptibility to HIV infection, although CD4-positive murine cells are fully competent for binding the viral envelope protein gp120 [3638]. The second phenomenon concerned the distinct tropisms of different HIV-1 isolates for various $\mathrm{CD}^{+}$ human target cell types in vitro. Some virus strains, adapted for growth in transformed T-cells, could only replicate in transformed T-cell lines and activated primary T-cells, whereas HIV-1 strains, adapted in peripheral blood mononuclear cells (PBMCs), only replicated in cells from the macrophage/monocyte lineage and activated primary T-cells $[39,40]$. These viruses were respectively designated T- and M-tropic and not only showed a different infection pattern but also have distinct significance for the spread of HIV-1 and disease course [40,41]. In fact, the viral isolates obtained from HIV-1-infected persons in an early stage of infection are predominantly $\mathrm{M}$-tropic, while those found at a later stage of disease progression towards AIDS are mostly Ttropic. All these data suggested the presence of distinct human cofactors, probably differentially expressed on the HIV-1 target cells, and making them susceptible for entry by either M- or T-tropic HIV-1 strains. Finally, an orphan GPCR was identified as a cofactor for HIV-1 [39]. This coreceptor, designated 'fusin' because of its activity in env-mediated cell fusion, acted selectively for T-tropic isolates $[14,42]$. In addition, it was demonstrated that fusin had strong sequence homology with the peptidergic chemokine receptors. This provided also a direction for the identification of the cofactor for M-tropic isolates. Moreover, an earlier study already demonstrated that $\mathrm{CD}^{+}{ }^{+}$T-cells released some soluble HIV1 suppressor factors, which were identified as the CCchemokines RANTES, MIP- $1 \alpha$ and MIP-1 $\beta$ [18]. Soon after, the receptor that had precise specifity for these chemokines was recognized, and was designated CCR5 $[43,44]$. Not much later, five different groups identified the chemokine receptor CCR5 as the major coreceptor for Mtropic HIV-1 isolates [13,15-17,45]. When the natural ligand, SDF-1, of fusin was found, the corresponding receptor was renamed CXCR4 [46,47]. Ever since, these receptors were subject of many studies showing their importance in the transmission and pathogenesis of HIV.

\subsection{HIV entry process}

Based on the current knowledge, the process of HIV-1 entry into host cells can be divided into three discrete steps: gp120-CD4 binding, gp120-coreceptor binding and membrane fusion (Fig. 1). The process is initiated by the attachment of the viral envelope protein gp120 to the CD4 receptor. The CD4 molecule is mainly expressed on Tlymphocytes, macrophages and dendritic cells (DC). The CD4 binding site is located at the base of the gp120 core, which is a relatively acidic area that corresponds with the basic domain of the N-terminus of CD4 [48].

However, CD4 independent attachment has also been reported [49]. Namely, rectal and vaginal mucosal epithe- 


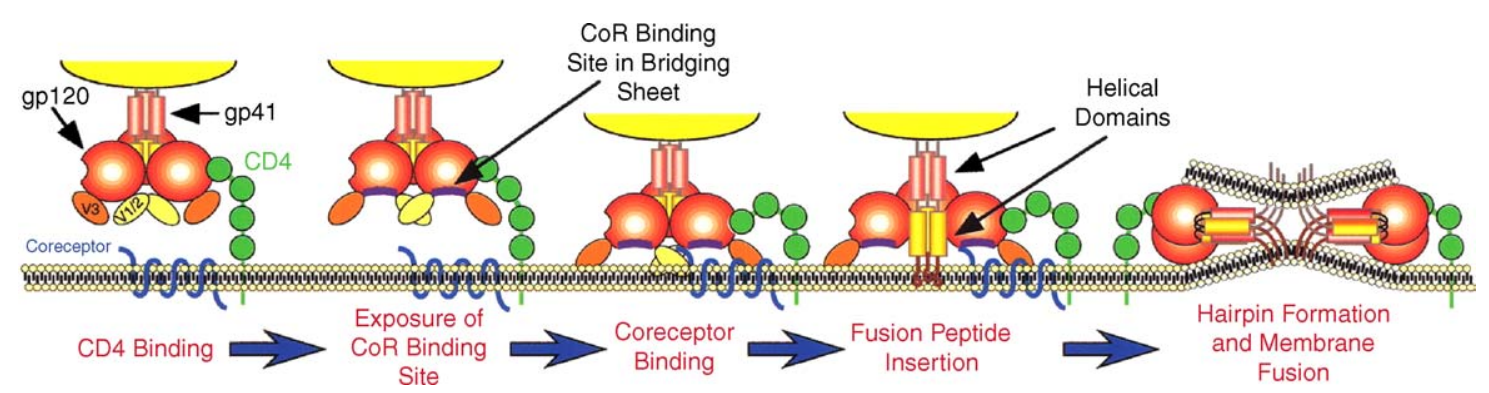

Fig. 1. Schematic presentation of the HIV-1 entry process. The entry process is initiated by the attachment of the viral envelope protein gp120 to the CD4 receptor, which induces conformational changes in the gp120 subunit setting free the coreceptor binding site on gp120. After binding of the glycoprotein with the chemokine/coreceptor, HIV-1 gp41 'unfolds' by a hinge mechanism followed by insertion of the fusion peptide into the cell membrane, anchoring the virus to the cellular membrane. Then, gp41 folds into a 'hairpin structure' and brings the cell membrane and the viral membrane into close proximity whereafter fusion can take place. Following membrane fusion, the viral contents are expelled into the cell (modified from Doms [57]).

lium, spermatocytes, astrocytes and oligodendrocytes that do not express CD4 can be infected to a low degree. In addition, DC that are distributed throughout mucosal tissues are also demonstrated to bind HIV-1 gp120 via a C-type lectin receptor, called DC-SIGN [50].

Binding of the highly conserved binding site of the env glycoprotein gp120 to CD4 induces conformational changes in the gp120 subunit [51,52]. This results in the exposure of the coreceptor-binding site that is positioned at the basis of the hypervariable V3 loop, a region that is normally masked by the V1 and V2 loops [52]. The V3 loop, one of the five hypervariable regions of the glycoprotein gp120 has been implicated in determining viral tropism. In addition, the V1 and V2 loop have been demonstrated to influence the effects of the V3 loop [53]. This conformational change results in binding of gp120 to the extracellular amino terminus of the chemokine receptor [54]. As mentioned earlier the two chemokine receptors, CCR5 and CXCR4, are shown to play a key role in HIV-1 entry.

However, at this level the envelope is not yet 'fusogenic'. Chemokine receptor binding is required in order to achieve the final conformational changes required for membrane fusion. Immediately following coreceptor binding, HIV-1 gp41 'unfolds' by a hinge mechanism, and the fusion peptide (N-terminal helices or helical region 2 (HR2)) bends away from the viral surface inserting into the cell membrane, anchoring the virus to the cellular membrane. This prehairpin intermediate exposes the distal carboxyterminal three-stranded coiled-coil (C-terminal helices or HR1). At this stage, the N-peptides are not yet associated with the Cpeptides which therefore remain vulnerable to inhibition by synthetic C-peptides like T-20. Subsequently, gp41 folds into the 'hairpin structure' and brings the amino terminus of the ectodomain (adjacent to the cell membrane) and the carboxyl terminus (attached to the viral membrane) into close proximity. Here, gp41 again forms a coiled-coil helical arrangement, in which the N-helices lie antiparallel within grooves created by the $\mathrm{C}$-helices [55]. The hairpin formation facilitates the contact between the virus and cell membranes, allowing the membranes to fuse. Following membrane fusion, the viral contents are expelled into the cell.
Importantly, some reports stated that after chemokine receptor binding, protein-disulfide isomerase (PDI) associates with CD4 and catalyzes the reduction of two of the nine disulfides of gp120. This disulfide bond restructuring within env may constitute the molecular basis of the coreceptor binding conformational changes that finally induce fusion competence [56].

Membrane fusion is a complex process, and it is currently estimated that four to six chemokine receptor molecules, multiple CD4 molecules and three to six env trimers are needed to form a fusion pore [57]. Thus, it is logical to assume that virus entry can depend also on receptor density and that env-receptor affinity can affect the rate and efficiency for infection.

\subsection{Viral tropism}

\subsection{1. 'Major coreceptors' of HIV-1: CXCR4 and CCR5}

After the identification of the chemokine receptors CXCR4 and CCR5 as the major coreceptors of HIV-1, a simple model was used to elucidate the tropism of HIV-1 strains. It can be explained by two considerations: the ability of the viral envelope to use CXCR4 and/or CCR5, and the expression of the chemokine receptors on the different $\mathrm{CD} 4^{+}$ target cells. T-tropic strains preferentially use CXCR4, the M-tropic strains prefer CCR5 and the dual-tropic strains use both. Additionally, T-cell lines express CXCR4, monocytes/ macrophages express CCR5 and primary T-cells express one or both chemokine receptors, CXCR4 or CCR5 [39,57].

Another nomenclature that has been used for a long time to distinguish between different HIV-1 strains was based on the ability of certain primary HIV-1 isolates to induce syncytia or 'giant cells' in T-cell lines. In this system, virus strains are termed either 'syncytium-inducing (SI)' or 'nonsyncytium-inducing (NSI)'. Herein, the SI and the NSI viruses generally correspond with respectively the T-tropic and the M-tropic virus strains [36,39].

However, several further studies have pointed out shortcomings of the two classification systems, SI/NSI and T-tropic/M-tropic. The relationship between coreceptor expression and permissiveness for entry of particular HIV-1 


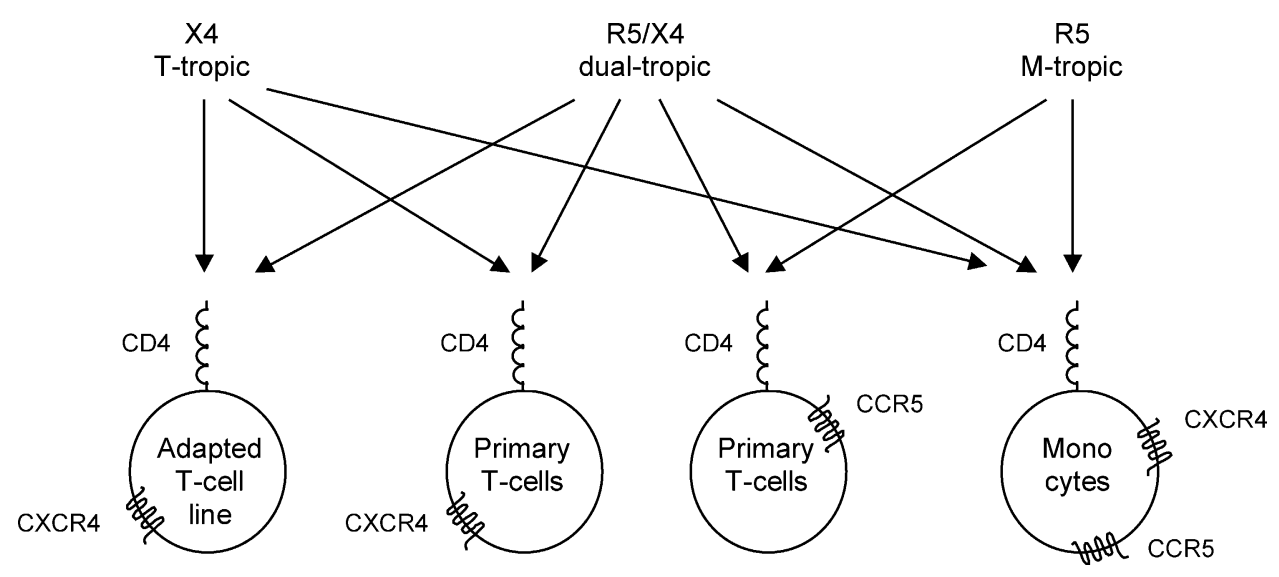

Fig. 2. Simple model of HIV-1 coreceptor usage and HIV-1 tropism. X4 strains (previously called T-tropic or SI strains) specifically infect cells expressing the chemokine receptor CXCR4, while R5 strains (previously called M-tropic or NSI strains) specifically infect cells expressing the chemokine receptor CCR5. Dual tropic or R5/X4 strains can use both CXCR4 and CCR5 to enter their target cells (modified from De Clercq and Schols [61]).

variants is very complex since a coreceptor can have differential capacity to support HIV-1 entry depending on which cells it is expressed.

For example, monocytes/macrophages (M/M) express CXCR4 in addition to CCR5. Several groups reported infections of primary cells of the M/M lineage by SI/T-tropic virus isolates, while others did not show any replication of Ttropic virus strains $[58,59]$. This can imply the existence of cell-specific CXCR4 or a post-entry replication hindrance [60]. Moreover, it was demonstrated that when CCR5transfected cells are infected with R5-strains they behave like SI strains. In addition, activated T-cells have been demonstrated to express CCR5, and thus allowing M-tropic strains to replicate [51]. In light of these findings on HIV-1 phenotype and chemokine receptor usage, these nomenclatures, SI/NSI and T/M-tropic, are no longer appropriate.

Therefore, the HIV-1 phenotype has been revised to indicate coreceptor usage, rather than the less defined characteristics of target cell tropism and SI-properties. HIV1 virus strains have now been designated as $\mathrm{X} 4$ strains (CXCR4-specific), R5 strains (CCR5-specific) or R5/X4 strains (dual-tropic) (Fig. 2) [61].

\subsection{2. 'Minor coreceptors' of HIV-1}

Studies have shown that, besides CXCR4 and CCR5, several other chemokine receptors can function as coreceptors for HIV-1-infection. Importantly, many of these studies applied coreceptor-transfected cells in vitro and their usage in vivo has not yet been demonstrated. Table 2 gives a short overview of the potential HIV-1 coreceptor repertoire.

\subsection{Course of HIV infection in vivo}

As mentioned earlier, distinct HIV-1 strains not only show a different infection pattern but they also emerge at different stages of disease progression $[39,41]$. To be more precise, it was determined that R5 viruses predominate in early asymptomatic stages of infection, while R5/X4 and X4 viruses appear at later stages of HIV-1 infection. Moreover, R5 viruses are responsible for transmission of HIV-1 as evidenced by the high degree of resistance to infection of individuals homozygous for a $32 \mathrm{bp}$ deletion in the gene encoding CCR5, who consequently lack a functional receptor $[19,20]$. The appearance of $\mathrm{X} 4$ viruses is associated with accelerated $\mathrm{CD} 4^{+}$T-cell decline and clinical progression towards AIDS [62-65].

Following infection, an initial burst of viremia is observed which results in a decrease in $\mathrm{CD}^{+} \mathrm{T}$-cells. Within weeks after infection, an immune response can be observed. This phenomenon causes a plasma viral load drop and a $\mathrm{CD} 4^{+} \mathrm{T}$-cell count increase, although not reaching preinfection levels. Then, a steady state, also known as clinical latency, is observed for an undetermined period of time $[66,67]$. Eventually, the asymptomatic steady state is lost when viral replication and resulting cellular destruction exceed the capacity of the immune response system [68]. Subsequently, the viral load rises again, the $\mathrm{CD}^{+} \mathrm{T}$-cell count declines enormously, resulting in a condition in which the immune system cannot defend itself, and opportunistic infections can occur. The latter symptomatic period of HIV1 pathogenesis (AIDS) corresponds with the appearance of

Table 2

HIV-1 coreceptor repertoire

\begin{tabular}{lll}
\hline Chemokine receptors & Chemokine ligands & Reference \\
\hline CCR2b & MCP-1, -2, -3, -4 & {$[145]$} \\
CCR3 & Eotaxin-1, -2, RANTES, & {$[45,145]$} \\
& MCP-2, -3, -4 & \\
CCR5 & RANTES, MIP-1 $\alpha$ & {$[45,145]$} \\
& and $\beta$, LD78 & \\
CCR8 & I-309 & {$[146,147]$} \\
CCR9 & TECK & {$[148]$} \\
CXCR4 & SDF-1 & {$[14,46]$} \\
CX3CR1 & Fractalkine & {$[149]$} \\
CXCR6 (STRL33/Bonzo) & CXCL16 & {$[150,151]$} \\
APJ & Not known & {$[148,152]$} \\
GPR15/BOB & Not known & {$[153,154]$} \\
\hline
\end{tabular}


X4 viruses in the plasma of HIV-1-infected persons [69-72]. To date, many research groups have been studying this coreceptor 'shift' extensively although still many questions remain.

In the most recent reports, it is hypothesized that certain mutations in the V3 loop of the viral envelope glycoprotein are strongly associated with the shift from R5 viruses to X4 viruses. In particular, basic amino acids at the V3 loop positions 11 and 25 very frequently distinguish $\mathrm{X} 4$ from R5 viruses [73-75]. The actual mutational pathway is as yet unexplored. In addition, it is known that dual-tropic R5/X4 viruses also emerge around the time of R5 to X4 transition, but also their evolutionary role is not certain $[69,76]$. Some groups demonstrated that progression from R5 to X4 occurred via an intermediate that has dual-tropic (R5/X4) [77] or even multitropic coreceptor usage such as CCR5, CCR3, CCR2b and CXCR4 [78]. It is believed that cellular and humoral components of the immune system cause selective pressure that results in diversification in env and alterations in coreceptor usage, but this remains largely unexplored.

\section{Chemokine receptor inhibitors}

The connection of the HIV and the chemokine field first began with the observation that HIV entry into cells could be blocked by certain chemokines (CC-chemokines) [18]. Since then, chemokine receptors constitute an important target for the development of anti-HIV therapies. It has been reported that rapid and extensive internalisation of CCR5 or CXCR4 is responsible for the anti-HIV-1 activity of their natural chemokine ligands $[79,80]$. However, the concept of using chemokines as antiretroviral therapeutics is restrained because of their short half-life $(<10 \mathrm{~min})$ and potential inflammatory side effects. Thereby, chemokines do not invariably act as HIV-suppressive agents. For instance, SDF1 has been demonstrated to increase the infectivity of R5 strains at the transcriptional level, while blocking the infection of $\mathrm{X} 4$ strains at the entry level [81]. It has been reported that higher levels of CC-chemokines (RANTES and MIP-1 $\alpha$ ) are associated with a slower progression of disease or even a HIV-free status [82,83]. However, it has also been observed that CC-chemokines can enhance HIV-1 infection in vitro in some systems, probably due to chemokine-induced cell activation [84-86]. Moreover, CC-chemokines might drive the evolution of less pathogenic R5 strains to the more pathogenic X4 isolates $[87,88]$. To overcome these limitations, new chemokine inhibitors have been designed, derived from the natural CCR5 and CXCR4 ligands. These modified chemokines should interact with the receptor and prevent HIV-1 infection by blocking relevant epitopes and/or inducing receptor internalisation without inducing signaling. In addition, new classes of antagonistic compounds are designed to effectively block HIV-1 virus entry, i.e. small-molecule compounds, peptides and monoclonal antibodies.
The strategy to block chemokine receptors has several advantages. First, blocking CCR5 and CXCR4 prevents viral entry rather than limit virus production by cells that have already become infected. In that way, CCR5 antagonists can prevent transmission of the virus while CXCR4 viruses can block the onset of disease progression towards AIDS. Second, CCR5 and CXCR4 inhibitors represent important additions to weapons now used to combat HIV and thus could complement existing antiretroviral drug strategies. Third, if they are antagonists that do not trigger any signals themselves through their target receptor, these agents are less likely to evoke immunological side effects, making them good candidates for prolonged maintenance treatment.

Although the use of coreceptor antagonists seems a very good approach to effectively inhibit HIV-1 entry into its host cells, some concerns raised with regard to the clinical use for long-term treatment of HIV-1 infections. Since people with a homozygeous 32 bp deletion in the CCR5 gene (CCR5 $\Delta 32 / \Delta 32$ ), consequently lacking functional CCR5 receptors on their cells, show a completely normal phenotype and are relatively resistant against R5 HIV-1 infection, blocking the CCR5 receptor should not be expected to raise any problems $[19,20]$. However, some groups reported that in few persons with a homozygeous 32 bp deletion that did get infected with HIV-1, progression to death is more rapid [89], which is probably due to the outgrowth of X4 viruses [90]. Moreover, a recent study has shown that there are significant interindividual and interpopulation differences in the copy number of a segmental duplication of the gene encoding for the CCR5 chemokine LD78 $\beta$. Possession of a $L D 78 \beta$ copy number lower than the population average is related with markedly enhanced HIV susceptibility. This susceptibility is even greater in individuals who also possess disease-accelerating CCR5 genotypes [91]. In addition, studies with CXCR4 knockout mice revealed defects in B-cell lymphopoiesis and bone-marrow myelopoiesis. Moreover, mice lacking CXCR4 exhibit hematopoietic and cardiac defects identical to those of SDF-1-deficient mice and die before birth [9294]. However, all these deficits are developmental and it is not known if SDF-1 and CXCR4 are essential for normal physiological processes after birth. If they are not, blocking CXCR4 to inhibit HIV entry would certainly be a very valuable approach. Indeed, Phase I/II clinical trials with several CXCR4 antagonists proved that blocking the SDF1/CXCR4 axis is safe and feasible (see further).

\subsection{Modified chemokines}

The chemokine LD78 $\beta$, a non-allelic isoform of MIP- $1 \alpha$, which only differs from LD78 $\alpha$ in 3 amino acids, proved very effective in suppressing R5 HIV-1 viruses in PBMCs [95] and monocytes/macrophages (M/M) [96]. LD78 $\beta$ is the most active natural CCR5 agonist that is described to date and the most potent chemokine to suppress R5 HIV-1 infection $[91,95,96]$. 
In contrast, intact RANTES actually has no anti-HIV-1 activity but only becomes antivirally active when it is truncated at the aminoterminal end by dipeptidyl peptidase IV (DPP IV), also called CD26. CD26 plays an important role in natural chemokine processing because of its posttranslational modification function [97]. RANTES(368 ) is such a processed form of RANTES that lacks two Nterminal residues [98]. By this truncation the chemokine loses its agonistic actvity, but shows the ability to potently block R5 viruses in an antagonistic manner [98,99]. A synthetic truncated form of RANTES, i.e. RANTES(9-68), lacking eight amino acids at its $\mathrm{N}$-terminus, also was antagonistic but less potently inhibited R5 HIV-1 strains than RANTES(3-68) [98-100].

Several derivatives of RANTES that bind to CCR5 and inhibit infection of lymphocytes and cells of the macrophage lineage with R5 viruses have been identified. Aminooxypentane (AOP)-RANTES was created by chemical modification of the aminoterminus. This derivative has been found to decrease HIV-1 infectivity in many cell types and showed reduced capacity to induce chemotaxis. In addition, like intact RANTES it induced down-modulation of surface CCR5 to early endosomes. However, AOPRANTES also prevented the recycling of CCR5 to the cell surface resulting in a long-lasting depletion of CCR5 [80]. Comparable results were obtained with the $N$-nonanoyl (NNY)-RANTES derivative that also reduced proinflammatory signaling through its interaction with CCR5 [101]. Extension of human RANTES by a single residue at the amino terminus also proved sufficient to produce a potent and selective antagonist. Methionylated RANTES (MetRANTES) was fully folded but completely inactive in calcium mobilisation and chemotaxis assays with the monocytic cell line THP-1 and antagonized the RANTESand MIP- $1 \alpha$-induced chemotaxis in these cells and in primary T-cells. Its antagonistic effect was selective since Met-RANTES had no effect on IL-8- or MCP-1-induced responses in these cells [102]. Another RANTES analog, by changing the first three aminoterminal amino acids of the native protein with a nonanoyl, thioproline and clyclohexylglycine, called PSC-RANTES, showed potent anti-HIV activity against R5 viruses in vitro and was also capable of preventing vaginal SHIV transmission in rhesus macaques [103]. All the RANTES analogs showed internalization and down-modulation of the CCR5 receptor, which may also explain their potent anti-HIV activity [103]. In addition it was reported that an aminooxypentane-linked variant of LD78 $\beta$, termed AOP-LD78 $\beta$, is about 10 -fold more active than AOP-RANTES at inhibiting HIV entry, making it the most effective chemokine-based inhibitor of HIV entry through CCR5 described to date [104].

In addition, some attempts have been made to generate an optimized CXCR4 antagonist by the addition of an aminoterminal methionine residue to the chemokine (Met-SDF-1). This derivative showed enhanced X4 HIV-1 inhibition, which was correlated with prolonged down- regulation of CXCR4 compared to unmodified SDF-1 [105]. Moreover, in vitro studies with Met-SDF-1 demonstrated that it induced a more pronounced intracellular calcium signaling [105].

All these data suggest a positive role for chemokines and their derivatives in controlling HIV-1 infection. However, because these derivatives, like the chemokines they are derived of, also are predicted to have inflammatory sideeffects when used therapeutically, new classes of antagonistic compounds were designed to effectively block HIV-1 infection, i.e. small-molecule compounds, peptides and monoclonal antibodies.

\subsection{Chemokine receptor antagonists}

The primary mechanism of coreceptor antagonist function does not rely on receptor down-modulation, but on receptor occupancy. As attempted with the design of modified chemokines, such inhibitors are unable to induce signaling and therefore implausible to indirectly augment virus replication or to induce inflammation. Several important coreceptor antagonists have been described so far: small-molecule inhibitors, peptidic inhibitors and also some monoclonal antibodies with specific anti-HIV-1 activity.

\subsubsection{CXCR4 antagonists}

5.2.1.1. The bicyclams. Shortly after the discovery that HIV is the cause of AIDS, the most extensively studied antiHIV drugs were then the reverse transcriptase inhibitors. However, these earlier compounds had to deal with high toxicity and a fast rate of virus resistance development.

In the search for new anti-HIV agents with better characteristics than the existing drugs, a novel class of compounds was discovered with potent and selective antiHIV activity, namely the bicyclams [106]. The prototype compound used for the development of these new agents was the monocyclam AMD1498 (1,4,8,11-tetraazacyclotetradecane), which itself was active at concentrations up to 400 (M, with a selectivity index of $>5$ (Fig. 3). AMD1498 was part of a project aimed at making new anti-HIV compounds that would gain anti-HIV activity by the formation of metal complexes using organic molecules, possible by the presence of four nitrogens in the centre of the cyclam ring. The bicyclams exist of two such macrocyclic rings, containing 12-14 members each, linked in various ways [107]. Two compounds, designated AMD1657 and AMD2763, were found active against HIV-1 and HIV-2 at a concentration of 0.14-1.4 (M, with a selectivity index of $>1000-10,000$. This antiviral activity was observed in different cell lines including PBMCs and with several HIV-1 and HIV-2 strains. In AMD1657 the cyclam moieties were linked with a direct carbon-carbon bridge creating two chiral centres, in AMD2763 via an aliphatic (propylene) bridge (Fig. 3). To examine at which stage the bicyclams interact with the viral life cycle, time-of-addition experiments were 
carried out, in which compounds are added at different time intervals after virus infection. Addition of AMD1657 and AMD2763 could only be delayed for 1-2 $\mathrm{h}$ without loss of activity. Thus, it appeared that the compounds interacted with an early process in the replication cycle following virus adsorption but preceding reverse transcription, i.e. virus-cell fusion or uncoating [106].

Further studies pointed out that bicyclam derivatives in which the two monocylam rings are connected by an aromatic linker, in stead of an aliphatic linker, inhibit HIV replication at concentrations of 1 to $10 \mathrm{ng} / \mathrm{ml}$, which is about 100 -fold lower than the concentration required for AMD2763 to inhibit HIV replication and about 100,000 times lower than the cytotoxic concentration $(>500 \mu \mathrm{g} / \mathrm{ml})$ [108]. The most potent bicyclam of these series and also the prototype is AMD3100, previously called JM3100 or SID791, in which the two cyclam moieties are tethered by a 1,4-phenylenebis(methylene)-bridge (Fig. 3) [108]. AMD3100 inhibited HIV-1 and HIV-2 replication with a $50 \%$ effective concentration of $1-10 \mathrm{nM}$ and provided complete protection of monocytes and lymphocytes at 10$30 \mathrm{ng} / \mathrm{ml}$. The compound also inhibited syncytium formation between cocultures of persistently infected HUT-78 cells (with the X4 HIV-1 strain IIIB) and uninfected MOLT-4 cells, albeit at higher concentrations $(1-5 \mu \mathrm{M})$. Structure-activity relationship studies demonstrated that the antiviral activity of the bicyclam analogues is dependent on the number of members (i.e. 12-14) in the two macrocyclic rings. Moreover, the length of the linker between the two rings and specific substitutions on the phenylenebis(methylene) linker are also important for their potency $[109,110]$. In addition, in line with the results of the time-of-addition experiments, which revealed that the bicyclams interact at a stage following virus adsorption but preceding reverse transcription, additional studies demonstrated that capsid proteins remained associated and virus did not have the possibility to uncoat in presence of AMD3100. Studies with AMD3100- and AMD2763-resistant viruses pointed to gp120 as the possible target molecule for the bicyclams because a number of mutations accumulate in the V3-V4 region of gp120, in viruses rendered resistant to the bicyclams [111]. Moreover, the molecular clones HIV-1 IIIB and HIV-1 NL4.3 remained sensitive to AMD3100 during up to 49-105 days [108,111]. More exactly, it took more than 60 passages in cell culture for the X4 HIV-1 strain, clone NL4.3, to become 300-400-fold resistant to AMD3100 [111-113].

At this time, the V3 loop was discovered to be very important in the viral fusion process and $\mathrm{M}$ - and $\mathrm{T}$-tropic strains were found to interact respectively with the chemokine receptors CCR5 and fusin, now designated CXCR4 $[14,15,17,42,45]$. Soon thereafter, it was shown by our group

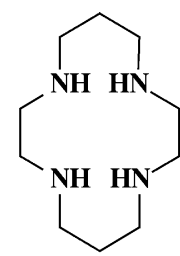

AMD1498

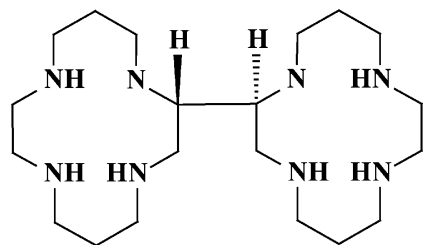

AMD1657<smiles>NCCCNCCCNCCCNCCCNCCCCN1CCCCCNCCC1</smiles>

AMD2763<smiles></smiles>

AMD3100<smiles>CCCCCCCCC(NC(=O)c1ccc(CNCc2ccccn2)cc1)C(=O)NC(C)c1cccc2ccccc12</smiles>

Fig. 3. Chemical structures of several small molecule CXCR4 antagonists: AMD1498, AMD1657, AMD2763 and AMD3100 (AnorMED) and KRH-1636 (Kureha Chemical Industry). 

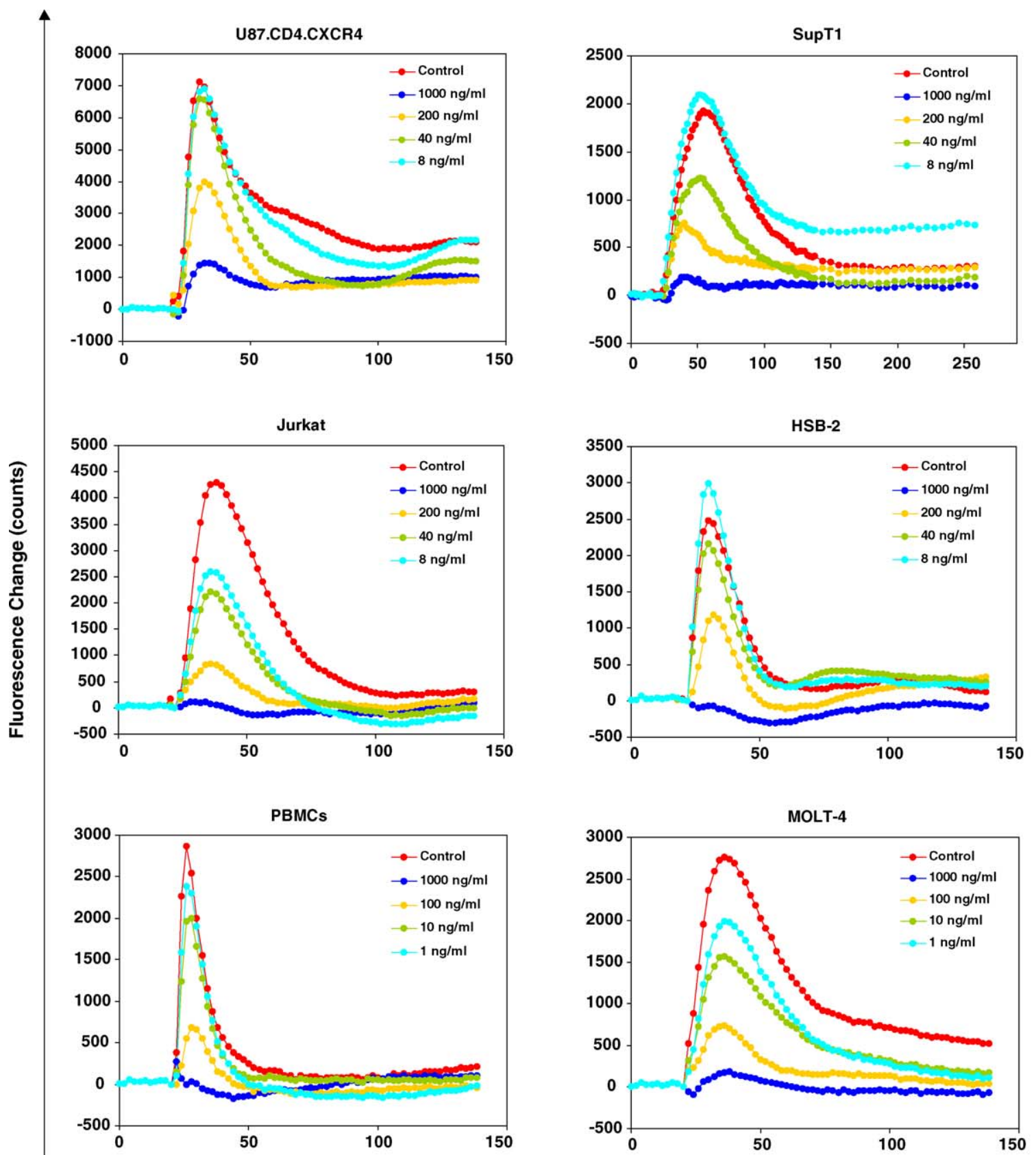

Time (seconds)

Fig. 4. Concentration-dependent inhibition of SDF-1/CXCR4-mediated intracellular calcium flux by AMD3100 in CXCR4-transfected human U87.CD4 cells, CXCR4 ${ }^{+}$human T-lymphoid SupT1, Jurkat, HSB-2 and MOLT-4 cells and freshly isolated human PBMCs. After loading of the cells with a fluorescent calcium indicator, Fluo-3, the cells were preincubated for $15 \mathrm{~min}$ with AMD3100 at the indicated concentrations, and then stimulated with SDF-1 at respectively 10, 20 , $30,20,100$ and $100 \mathrm{ng} / \mathrm{ml}$. The increase of the transient intracellular $\mathrm{Ca}^{2+}$ concentration was recorded by monitoring the change in green fluorescence of the total amount of cells as a function of time using the FLIPR.

that the bicyclam derivatives exhibit their strong and selective antiviral efficacy through their interaction with CXCR4 [114]. Indeed, AMD3100 showed activity against a wide variety of X4 and even R5/X4 HIV strains in PBMCs but not against R5 strains [61,71,115-117]. Moreover, further studies showed that AMD3100 potently inhibits the intracellular calcium signaling induced by SDF-1, the natural ligand of CXCR4, in many cell types (Fig. 4). Furthermore, also the SDF-1-induced chemotaxis and internalisation could be dose-dependently blocked by AMD3100 [115,116,118]. Additionally, the chemokine receptor inhibition by AMD3100 is strictly confined to its interaction with CXCR4 and not with any 

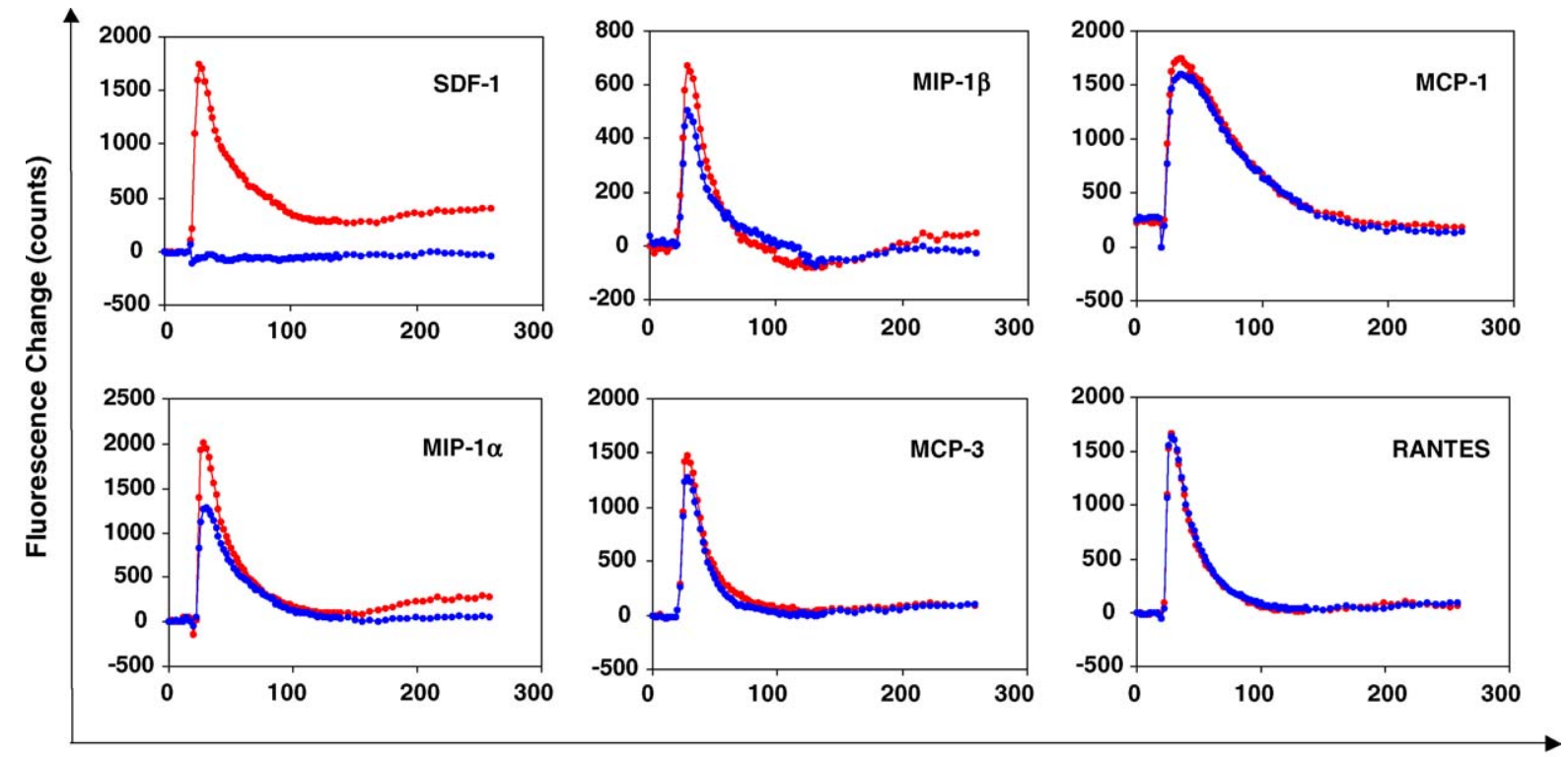

Time (seconds)

$\longrightarrow$ Control $\longrightarrow$ AMD3100 $25 \mu \mathrm{gg} / \mathrm{ml}$

Fig. 5. Specific inhibition by AMD3100 through CXCR4 of the calcium signaling induced by various chemokines in purified monocytes: SDF-1 (ligand for CXCR4), MIP-1 $\beta$ (ligand for CCR5), MCP-1 (ligand for CCR2), MIP-1 $\alpha$ (ligand for CCR1 and CCR5), MCP-3 (ligand for CCR1, CCR2 and CCR3) and RANTES (ligand for CCR1, CCR3 and CCR5). Fluo-3-loaded monocytes were preincubated for 15 min with AMD3100 at $25 \mu \mathrm{g} / \mathrm{ml}$ and then stimulated with chemokines all at $50 \mathrm{ng} / \mathrm{ml}$. The increase of the transient intracellular $\mathrm{Ca}^{2+}$ concentration was recorded by monitoring the change in fluorescence of cells as a function of time using the FLIPR.

other chemokine receptor [118]. As shown in Fig. 5, AMD3100 is able to block the SDF-1-induced $\mathrm{Ca}^{2+}$ flux in purified monocytes, but not the calcium signaling induced by MIP-1 $\beta$, MCP-1, MIP- $1 \alpha$, MCP-3 and RANTES.

The first human study of AMD3100 evaluated the safety, bioavailability, and single dose pharmacokinetics of progressively higher doses of AMD3100, from 10 to $80 \mu \mathrm{g} / \mathrm{kg}$, administered intravenously over $15 \mathrm{~min}$ in successive cohorts of three to five healthy volunteers [119]. Five volunteers also received a single subcutaneous injection ( 40 or $80 \mu \mathrm{g} / \mathrm{kg}$ ) and three volunteers also received oral doses (80 or $160 \mu \mathrm{g} / \mathrm{kg}$ ). AMD3100 was well tolerated in all patients by all routes of administration. Six of the 12 subjects $(50 \%)$ had mild, transient symptoms, primarily gastrointestinal in nature. Most patients experienced a transient, dose-dependent increase in white blood cell count 1.5-3 times baseline values within $6 \mathrm{~h}$ of the infusion, which returned nearly to baseline by $24 \mathrm{~h}$ after dosing. The pharmacokinetic profiles were dose proportional with an estimated half-life of $3.6 \mathrm{~h}$. Absorption following subcutaneous administration was very good (bioavailability $87 \%$ ), but no drug was detectable in the blood following oral dosing.

In the next study safety, pharmacokinetics and antiviral activity of AMD3100 was evaluated in HIV-infected persons [120]. AMD3100 was administered for 10 days by continuous intravenous infusion in an open-label, dose escalation study from 2.5 up to $160 \mu \mathrm{g} / \mathrm{kg} / \mathrm{h}$. Forty HIVinfected patients with viral load $>5000$ copies $/ \mathrm{ml}$, either on stable antiretroviral regimens or off therapy were enrolled. At the time of the clinical study, NSI/SI phenotype was determined in an MT-2 cell assay. The HIV phenotype was SI $(30 \%)$, NSI $(45 \%)$, or not tested $(25 \%)$. One patient $(5 \mu \mathrm{g} / \mathrm{kg} / \mathrm{h})$ had serious and possibly drug-related thrombocytopenia. Two patients (40 and $160 \mu \mathrm{g} / \mathrm{kg} / \mathrm{h}$ ) had unexpected, though not serious, premature ventricular contractions. Most patients in the 80 and $160 \mu \mathrm{g} / \mathrm{kg} / \mathrm{h}$ cohorts had paresthesias. Only one patient, the patient whose virus was confirmed to use purely CXCR4, and who received the highest dose studied $(160 \mu \mathrm{g} / \mathrm{kg} / \mathrm{h})$ had a significant 0.9 $\log _{10}$ copies/ml HIV RNA drop at day 11 . In conclusion, AMD3100 was the first CXCR4 antagonist to demonstrate a clinical anti-HIV effect and warrants the development of orally bioavailable CXCR4 antagonists for HIV treatment.

5.2.1.2. Other CXCR4 antagonists. Several other molecules have been described as anti-HIV agents owing their antiviral activity to their specific interaction with CXCR4. For example, some peptidic agents are described with potent antiretroviral activity. A disadvantage of such peptidic compounds is their complex synthesis, which will contribute considerably to a high cost of therapy. Moreover, no orally bioavailable peptidic agents have been described to date so if they were to move into the clinic they must be administered by injection.

For example, T22, $\left\{\mathrm{Tyr}^{5,12}, \mathrm{Lys}^{7}\right\}$-polyphemusin, is a cationic 18-amino acid peptide, derived from horseshoe crab blood cells. It was shown to inhibit replication of both 
laboratory strains and primary isolates of HIV-1 by specific binding to the N-terminus and two extracellular loops of CXCR4 [121]. T22 did not induce signaling or receptor down modulation at concentrations required for inhibition of infection $(200 \mathrm{nM})$. Studies with a derivative of T22, called T134, demonstrated that this compound efficiently inhibits the replication of an AMD3100-resistant virus strain, suggesting that the binding sites for AMD3100 and T22 only partially overlap [122], although they both block the binding of the CXCR4-specific mAb 12G5 and the natural ligand SDF-1 to CXCR4. Tamamura et al. also reported on a second analog of T22, the 14-residue peptide called T140, which showed stronger inhibitory activity against HIV-1 entry [123].

ALX40-4C ( $N$ - $\alpha$-acetyl-nona-D-arginine (Arg) amide) is a (poly)peptide of nine Arg residues stabilized by terminal protection and inclusion of D-amino acids [124]. Initially it was characterized as an inhibitor of the HIV-1 Tat-trans-activation response element (TAR) interaction [125]. ALX40-4C inhibits HIV-1 NL4-3 in the nanomolar range $\left(\mathrm{IC}_{50}\right.$ of $\left.3 \mathrm{nM}\right)$ in the HUT-78 T-cell line and in PBMCs. In addition, it was demonstrated that ALX40-4C inhibited entry of X4, but not R5 HIV-1 strains. ALX40-4C also inhibited primary R5/X4 virus isolates, but only when cells expressed CXCR 4 alone, while infection of $\mathrm{CCR}^{+} /$ CXCR $4^{+}$double positive cells by $\mathrm{R} 5 / \mathrm{X} 4$ virus strains was not inhibited by ALX40-4C. Moreover, addition of ALX40-4C to cells expressing CXCR4 prevented SDF1-induced changes in intracellular calcium and prevented binding of an anti-CXCR4 mAb, clone 12G5. The epitope recognized by the $12 \mathrm{G} 5 \mathrm{mAb}$ resides in the first and second extracellular loops, the same region of CXCR4 that is used by both dual- and T-tropic HIV-1 strains and that overlaps with the activation site of SDF-1. In addition, Doranz et al. described that ALX40-4C was well tolerated in phase I/II clinical trials in humans, but no significant reductions in viral load were noted [126]. Furthermore, ALX40-4C was shown to be an antagonist to APJ, a GPCR that could serve as an alternative coreceptor for HIV-1 in the central nervous system [127].

CGP64222 is a basic peptoid oligomer of nine residues that inhibits the replication of a wide range of laboratory strains of HIV-1 and HIV-2 in MT-4 cells [128]. Besides its activity against Tat/TAR binding [129], the compound was also shown to inhibit HIV infection through a selective interaction with the CXCR4 receptor. This was demonstrated by the fact that CGP64222 proved inactive in MT-4 cells against HIV-1 strains that are resistant to the bicyclams and the compound inhibited SDF-1-induced calcium signaling [128].

KRH-1636 (Kureha Chemical Industries) is a smallmolecule CXCR4 antagonist that has a potent anti-HIV activity both in vivo and in vitro (Fig. 3). The compound selectively inhibited infection of X4 virus strains including several clinical isolates without affecting R5 HIV-1. It also inhibited binding of the CXC chemokine, SDF-1, to CXCR4 specifically and subsequent signal transduction. KRH-1636 prevented monoclonal antibodies from binding to CXCR4 without down-modulation of the coreceptor. Moreover, KRH-1636 showed potent antiviral activity in the human peripheral blood lymphocytes/severe combined immunodeficiency (hu-PBL-SCID) mouse model. Furthermore, this compound was absorbed into the blood after intraduodenal administration as judged by anti-HIV-1 activity and liquid chromatography in the plasma of rats [130].

AMD070 (AnorMED) is a novel orally bioavailable CXCR4 antagonist that potently inhibited $\mathrm{X} 4$ viruses at $\mathrm{EC}_{50}$ varying between 1 and $20 \mathrm{nM}$ in T cell lines, CXCR4transfected cell lines and PBMCs [131]. A Phase Ib/IIa trial to evaluate the potential of AMD070 as an anti-HIV drug in HIV-infected patients is just recently initiated.

\subsubsection{CCR5/CXCR4 antagonist}

Recently our group presented a CCR5/CXCR4 antagonist, called AMD3451 as the first low-molecular-weight anti-HIV agent with selective HIV coreceptor, CCR5 and CXCR4 interaction. AMD3451 is an $N$-pyridinylmethyl cyclam analog (Fig. 6A), which shows antiviral activity against a wide variety of R5, R5/X4 and X4 strains of HIV-1 and HIV-2 $\left(\mathrm{IC}_{50}\right.$ ranging from 1.2 to $\left.26.5 \mu \mathrm{M}\right)$ in various Tcell lines, CCR5- or CXCR4-transfected cells, PBMCs and monocytes/macrophages [132]. AMD3451 also inhibited $\mathrm{R} 5, \mathrm{R} 5 / \mathrm{X} 4$ and $\mathrm{X} 4 \mathrm{HIV}-1$ primary clinical isolates in PBMCs $\left(\mathrm{IC}_{50}\right.$ : 1.8-7.3 $\left.\mu \mathrm{M}\right)$. A PCR-based viral entry assay revealed that AMD3451 blocks R5 and X4 HIV-1 infection at the virus entry stage. AMD3451 dose-dependently inhibited the intracellular $\mathrm{Ca}^{2+}$ signaling induced by the CXCR4 ligand SDF-1 in CXCR4-transfected cells, as well as the RANTES-induced $\mathrm{Ca}^{2+}$ flux CCR5-transfected cells. The compound did not interfere with any other chemokine receptor, nor did it induce intracellular $\mathrm{Ca}^{2+}$ signaling by itself. AMD3451 also inhibited the SDF-1- and MIP-1 $\beta$ induced chemotaxis in a dose-dependent manner and was able to block the SDF-1- and LD78 $\beta$-induced endocytosis in CXCR4- and CCR5-transfected cells. Moreover, studies showed that the compound interacts in a different manner with CXCR4 than the specific CXCR4 antagonist AMD3100 since AMD3451 did not inhibit but enhanced the binding of anti-CXCR4 mAbs (such as clone 12G5) at the cell surface [132]. The precise interaction sites of AMD3451 with CCR5 and CXCR4 have yet to be elucidated, however this study demonstrates that it is possible to develop compounds that interact with both HIV-1 coreceptors. Also because of their dual interaction with both CXCR4 and CCR5 and, consequently, their potential to block cellular infection of R5, R5/X4 and X4 viruses, these compounds can be important for the development of an effective anti-HIV microbicide.

\subsubsection{CCR5 antagonists}

The first low molecular weight CCR5 antagonist with antiviral activity that was described was TAK-779 $(\mathrm{N}, \mathrm{N}-$ 
(A)<smiles>Clc1cc(CN2CCCNCCNCCCNCC2)cc(Cl)n1</smiles>

AMD3451

(B)<smiles>Cc1ccc(-c2ccc3c(c2)C=C(C(=O)Nc2ccc(C[N+](C)(C)C4CCOCC4)cc2)CCC3)cc1</smiles><smiles>CCON=C(c1ccc(Br)cc1)C1CCN(C2(C)CCN(C(=O)c3c(C)cc[n+]([O-])c3C)CC2)CC1</smiles><smiles>CCCCN1C(=O)C(C(O)C2CCCCC2)NC(=O)C12CCN(Cc1ccc(Oc3ccc(C(=O)O)cc3)cc1)CC2</smiles><smiles>COC[C@H](c1ccc(C(F)(F)F)cc1)N1CCN(C2(C)CCN(C(=O)c3c(C)ncnc3C)CC2)CC1C</smiles>

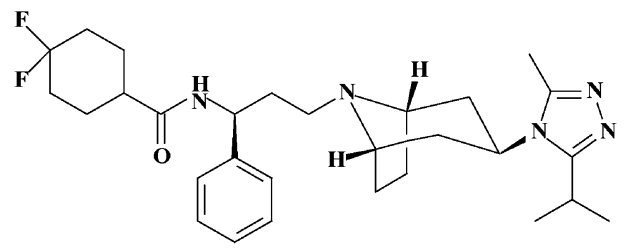

UK-427,857

Fig. 6. (A) Chemical structure of the dual CCR5/CXCR4 antagonist AMD3451 (AnorMED). (B) Chemical structures of several small molecule CCR5 antagonists: TAK-779 (Takeda Chemicals), SCH-C (SCH-351125) (Schering-Plough), SCH-D (SCH-417690) (Schering-Plough), UK-427,857 (Pfizer Inc) and GW873140 (Ono Pharmaceutical/Glaxo Smith Kline).

dimethyl- $N$-[4-[[[2-(4-methylphenyl)-6,7-dihydro-5H-benzocyclohepten-8-yl]carbonyl]amino]benzyl]tetrahydro- $2 \mathrm{H}$ pyran-4-ammonium chloride) (Takeda Chemicals) (Fig. 6B) [133]. It was shown to inhibit R5, but not X4, virus replication with laboratory-adapted strains and clinical isolates without activating or downregulating CCR5. The compound did not inhibit the binding of RANTES, eotaxin, TARC or SDF-1 to respectively CCR1-, CCR3-, CCR4- or CXCR4-transfected cells. However, TAK-779 inhibited the binding of MCP-1- to CCR2b-transfected cells. It was further demonstrated that the binding of TAK-779 and interaction with CCR5 can be assigned to a cavity formed between transmembrane helices $1-3$, and 7 near the extracellular surface of the receptor [134].

SCH-C (Schering-Plough) is the most potent CCR5 antagonist described to date. The compound, also designated SCH-351125, is an oxime-piperidine compound with potent activity against R5 HIV-1 strains in U87.CD4 cells transfected with CCR5, but not against X4 strains in CXCR4-expressing cells (Fig. 6B). As shown by multiple receptor binding and signal transduction assays, $\mathrm{SCH}-\mathrm{C}$ is a highly specific CCR5 antagonist [135]. In addition, SCH-C was demonstrated to have broad and potent antiviral activity against primary R5 isolates in vitro and showed a favorable pharmacokinetic profile in rodents and primates. Later, $\mathrm{SCH}-\mathrm{C}$ has shown in vivo antiviral efficacy in clinical studies by reducing the plasma viremia in R5 HIV-1-infected persons [136]. Recently, a derivative of SCH-C, SCH-D or SCH-417690 was presented (Fig. 6B) [137]. This compound is about 10-fold more potent against a panel of primary R5 isolates compared with SCH-C, and is viral genotype independent. SCH-D is currently undergoing phase II clinical trials.

Two other recently described CCR5 antagonists are GW873140, a spiroketopiperazine based agent (Ono Phar- 
maceutical/Glaxo Smith Kline) [138,139] and UK-427,857 (Pfizer) (Fig. 6B) [140]. Both compounds exerted potent antiviral activity against a wide spectrum of R5 laboratory strains and primary isolates and revealed favorable oral bioavailability. At this time, both compounds are under clinical investigation (Phase II/III studies) [138-140].

Anti-coreceptor mAbs that inhibit HIV-1 entry represent another class of blocking HIV agents. PRO 140 (Progenics Pharmaceuticals, NY) is an anti-CCR5 mAb that potently inhibits HIV-1 entry at concentrations that do not affect CCR5 chemokine receptor activity and showed to be genetic-subtype-independent [141]. A recent study also showed that PRO140 was able to control HIV-1-infection in the hu-PBL-SCID mouse model [142].

\section{Concluding remarks}

The crucial role of the cellular CD4 receptor in viral entry of the host cells by the human immunodeficiency virus (HIV) has since long been established. Almost a decade ago, it has been discovered that HIV also requires one of the chemokine receptors, CCR5 or CXCR4, as a coreceptor for successful entry into the target cell. These two G proteincoupled seven transmembrane (7TM) receptors play a prominent role in the transmission of HIV and during disease progression towards AIDS. Macrophage-tropic HIV strains, using CCR5 as their main coreceptor, represent the major virus subtype that is encountered in individuals in the early stages of infection. These R5 viruses are responsible for transmission of the disease via sexual intercourse. These viruses do not severely affect the $\mathrm{CD} 4^{+} \mathrm{T}$-cell count of a $\mathrm{HIV}$-infected person. Disease progression towards AIDS is often closely correlated with the emergence of CXCR4using (X4) virus strains, which rapidly destroy the immune system by depletion of the $\mathrm{CD} 4^{+} \mathrm{T}$-lymphocyte population. This review described the development of potent and selective antagonists of both the CCR5 and CXCR4 chemokine receptors, and exploring further their therapeutic potential for the treatment of HIV-infected persons.

A class of chemical compounds, designated the bicyclams, were described in our laboratory as potent anti-HIV agents that were active against a broad range of HIV-1 and HIV-2 strains, but not against any other RNA or DNA virus. The precise mechanism of action of the bicyclams remained unknown, until, following the discovery of the chemokine receptors as cofactors for HIV entry, it was demonstrated that they specifically interact with CXCR4. The bicyclam AMD3100 (1,1'-[1,4-phenylenebis-(methylene)]-bis-1,4,8,11-tetraazacyclotetradecane), the most potent compound of this series, showed antiviral activity in the nanomolar concentration range against a wide range of $\mathrm{X} 4$ and even dual tropic R5/X4 HIV-1 strains in PBMCs.

By means of mutational analysis studies, it was shown that two aspartate residues at positions 171 (TM IV) and 262 (TM VI) of CXCR4 are crucial for the high-affinity binding of AMD3100 to CXCR4. Elucidation of these molecular interaction sites of AMD3100 revealed new insights for the design of novel CXCR4 inhibitors. As the in vitro results were very promising, the pharmacokinetics, safety and antiviral efficacy of AMD3100 were evaluated in phase I and II clinical trials [143]. These studies demonstrated for the first time that a cellular receptor, CXCR4, is a suitable anti-HIV-1 target in vivo. With this information, further investigation was done to design a novel non-macrocyclic, orally bioavailable CXCR4 antagonist. This led to the development of a new generation of non-cyclic and orally bioavailable CXCR4 antagonists, of whom AMD070 was selected as the new lead compound. AMD070 showed strong and specific antagonistic activity against SDF-1/CXCL12-induced signaling and had potent antiviral activity against various HIV-1 laboratory-adapted and primary $\mathrm{X} 4$ isolates. This compound is currently being evaluated in phase I/II clinical studies.

In addition, our studies not only revealed potential and valuable CXCR4 antagonists but also a CCR5/CXCR4 dual antagonist, which shows specific interaction with both HIV1 coreceptors, as assessed in diverse antagonistic assays. The CCR5/CXCR4 antagonist, designated AMD3451, has antiviral activity against a wide range of HIV strains and primary isolates in many different cell types. Although AMD3451 has less potent antagonistic and antiviral activity compared to the previously described specific CCR5 and CXCR4 antagonists, it is very appealing to study in which way it is able to interact with both receptors, especially since it is assumed that both CCR5 and CXCR4 have to be targeted to effectively inhibit HIV-1 infection.

CCR5 is a particular attractive drug target as CCR5 $\Delta 32 /$ $\Delta 32$ homozygote persons exhibit no consequences of being CCR5 negative. Several CCR5 antagonists, such as GW873140 and UK-427,857, proceed or will proceed to clinical phase III studies. However, a concern for the use of CCR5 inhibitors is the possibility for viruses to escape by evolving to use CXCR4, which is associated with disease progression. Studies have shown that R5 viruses can indeed adapt to use CXCR4 to escape CCR5 inhibitors [87].

We conclude from these studies that CXCR4 and CCR5 antagonists will be highly suitable anti-HIV drugs to combat AIDS in the near future. The combination of a CCR5 and a CXCR4 antagonist or a more potent dual antagonist with already existing anti-HIV agents will certainly be a great step forward in anti-HIV drug research.

\section{References}

[1] Barre-Sinoussi F, Chermann JC, Rey F, Nugeyre MT, Chamaret S, Gruest J, et al. Isolation of a T-lymphotropic retrovirus from a patient at risk for acquired immune deficiency syndrome (AIDS). Science 1983;220:868-71.

[2] Chermann JC, Barre-Sinoussi F, Dauguet C, Brun-Vezinet F, Rouzioux $\mathrm{C}$, Rozenbaum $\mathrm{W}$, et al. Isolation of a new retrovirus in a patient at risk for acquired immunodeficiency syndrome. Antibiot Chemother 1983;32:48-53. 
[3] Pomerantz RJ, Horn DL. Twenty years of therapy for HIV-1 infection. Nat Med 2003;9:867-73.

[4] Hu DJ, Dondero TJ, Rayfield MA, George JR, Schochetman G, Jaffe $\mathrm{HW}$, et al. The emerging genetic diversity of HIV. The importance of global surveillance for diagnostics, research, and prevention. JAMA 1996;275:210-6.

[5] De Leys R, Vanderborght B, Vanden Haesevelde M, Heyndrickx L, van Geel A, Wauters C, et al. Isolation and partial characterization of an unusual human immunodeficiency retrovirus from two persons of West-central African origin. J Virol 1990;64:1207-16.

[6] Erickson J. Virology. In: HIV resistance and implications for therapy. Atlanta: Medicom Inc, 1998.

[7] Weiss RA. Gulliver's travels in HIVland. Nature 2001;410:963-7.

[8] Blankson JN, Persaud D, Siliciano RF. The challenge of viral reservoirs in HIV-1 infection. Annu Rev Med 2002;53:557-93.

[9] Chun TW, Fauci AS. Latent reservoirs of HIV: obstacles to the eradication of virus. Proc Natl Acad Sci USA 1999;96:10958-61.

[10] Aquaro S, Calio R, Balzarini J, Bellocchi MC, Garaci E, Perno CF. Macrophages and HIV infection: therapeutical approaches toward this strategic virus reservoir. Antiviral Res 2002;55:209-25.

[11] Richman DD. HIV chemotherapy. Nature 2001;410:995-1001.

[12] Wei X, Decker JM, Liu H, Zhang Z, Arani RB, Kilby JM, et al. Emergence of resistant human immunodeficiency virus type 1 in patients receiving fusion inhibitor (T-20) monotherapy. Antimicrob Agents Chemother 2002;46:1896-905.

[13] Doranz BJ, Berson JF, Rucker J, Doms RW. Chemokine receptors as fusion cofactors for human immunodeficiency virus type 1 (HIV-1). Immunol Res 1997;16:15-28.

[14] Feng Y, Broder CC, Kennedy PE, Berger EA. HIV-1 entry cofactor: functional cDNA cloning of a seven-transmembrane, $G$ proteincoupled receptor. Science 1996;272:872-7.

[15] Alkhatib G, Combadiere C, Broder CC, Feng Y, Kennedy PE, Murphy PM, et al. CC CKR5: a RANTES, MIP-1alpha, MIP-1beta receptor as a fusion cofactor for macrophage-tropic HIV-1. Science 1996;272:1955-8.

[16] Deng H, Liu R, Ellmeier W, Choe S, Unutmaz D, Burkhart M, et al. Identification of a major co-receptor for primary isolates of HIV-1. Nature 1996;381:661-6.

[17] Dragic T, Litwin V, Allaway GP, Martin SR, Huang Y, Nagashima $\mathrm{KA}$, et al. HIV-1 entry into CD4+ cells is mediated by the chemokine receptor CC-CKR-5. Nature 1996;381:667-73.

[18] Cocchi F, DeVico AL, Garzino-Demo A, Arya SK, Gallo RC, Lusso P. Identification of RANTES, MIP- $1 \alpha$, and MIP- $1 \beta$ as the major HIVsuppressive factors produced by $\mathrm{CD}^{+} \mathrm{T}$ cells. Science 1995;270:1811-5.

[19] Samson M, Libert F, Doranz BJ, Rucker J, Liesnard C, Farber CM, et al. Resistance to HIV-1 infection in caucasian individuals bearing mutant alleles of the CCR-5 chemokine receptor gene. Nature 1996;382:722-5.

[20] Liu R, Paxton WA, Choe S, Ceradini D, Martin SR, Horuk R, et al. Homozygous defect in HIV-1 coreceptor accounts for resistance of some multiply-exposed individuals to HIV-1 infection. Cell 1996;86:367-77.

[21] Dean M, Carrington M, Winkler C, Huttley GA, Smith MW, Allikmets R, et al. Genetic restriction of HIV-1 infection and progression to AIDS by a deletion allele of the CKR5 structural gene. Hemophilia Growth and Development Study, Multicenter AIDS Cohort Study, Multicenter Hemophilia Cohort Study, San Francisco City Cohort, ALIVE Study. Science 1996;273:1856-62.

[22] Baggiolini M. Chemokines and leukocyte traffic. Nature 1998;392:565-8.

[23] Murphy PM. International Union of Pharmacology. XXX. Update on chemokine receptor nomenclature. Pharmacol Rev 2002;54:227-9.

[24] Olson TS, Ley K. Chemokines and chemokine receptors in leukocyte trafficking. Am J Physiol Regul Integr Comp Physiol 2002;283:R7-28.

[25] Lodi PJ, Garrett DS, Kuszewski J, Tsang ML, Weatherbee JA, Leonard WJ, et al. High-resolution solution structure of the beta chemokine hMIP-1 beta by multidimensional NMR. Science 1994;263:1762-7.

[26] Horuk R, Chitnis CE, Darbonne WC, Colby TJ, Rybicki A, Hadley TJ, et al. A receptor for the malarial parasite Plasmodium vivax: the erythrocyte chemokine receptor. Science 1993;261:1182-4.

[27] Nibbs RJ, Wylie SM, Yang J, Landau NR, Graham GJ. Cloning and characterization of a novel promiscuous human beta-chemokine receptor D6. J Biol Chem 1997;272:32078-83.

[28] Townson JR, Nibbs RJ. Characterization of mouse CCX-CKR, a receptor for the lymphocyte-attracting chemokines TECK/mCCL25, SLC/mCCL21 and MIP-3beta/mCCL19: comparison to human CCX-CKR. Eur J Immunol 2002;32:1230-41.

[29] Luster AD, Greenberg SM, Leder P. The IP-10 chemokine binds to a specific cell surface heparan sulfate site shared with platelet factor 4 and inhibits endothelial cell proliferation. J Exp Med 1995;182:21931.

[30] Rot A. Endothelial cell binding of NAP-1/IL-8: role in neutrophil emigration. Immunol Today 1992;13:291-4.

[31] Kuschert GS, Coulin F, Power CA, Proudfoot AE, Hubbard RE, Hoogewerf AJ, et al. Glycosaminoglycans interact selectively with chemokines and modulate receptor binding and cellular responses. Biochemistry 1999;38:12959-68.

[32] Hoogewerf AJ, Kuschert GS, Proudfoot AE, Borlat F, Clark-Lewis I, Power CA, et al. Glycosaminoglycans mediate cell surface oligomerization of chemokines. Biochemistry 1997;36:13570-8.

[33] Dalgleish AG, Beverley PC, Clapham PR, Crawford DH, Greaves MF, Weiss RA. The CD4 (T4) antigen is an essential component of the receptor for the AIDS retrovirus. Nature 1984;312:763-7.

[34] Klatzmann D, Champagne E, Chamaret S, Gruest J, Guetard D, Hercend T, et al. T-lymphocyte T4 molecule behaves as the receptor for human retrovirus LAV. Nature 1984;312:767-8.

[35] Maddon PJ, Dalgleish AG, McDougal JS, Clapham PR, Weiss RA, Axel R. The T4 gene encodes the AIDS virus receptor and is expressed in the immune system and the brain. Cell 1986;47:333-48.

[36] Clapham PR, Blanc D, Weiss RA. Specific cell surface requirements for the infection of CD4-positive cells by human immunodeficiency virus types 1 and 2 and by Simian immunodeficiency virus. Virology 1991;181:703-15.

[37] Dragic T, Charneau P, Clavel F, Alizon M. Complementation of murine cells for human immunodeficiency virus envelope/CD4mediated fusion in human/murine heterokaryons. J Virol 1992;66:4794-802.

[38] James W, Weiss RA, Simon JH. The receptor for HIV: dissection of CD4 and studies on putative accessory factors. Curr Top Microbiol Immunol 1996;205:137-58.

[39] Berger EA, Murphy PM, Farber JM. Chemokine receptors as HIV-1 coreceptors: roles in viral entry, tropism, and disease. Ann Rev Immunol 1999;17:657-700.

[40] Littman DR. Chemokine receptors: keys to AIDS pathogenesis? Cell 1998;93:677-80.

[41] Miedema F, Meyaard L, Koot M, Klein MR, Roos MT, Groenink M, et al. Changing virus-host interactions in the course of HIV-1 infection. Immunol Rev 1994;140:35-72.

[42] Berson JF, Long D, Doranz BJ, Rucker J, Jirik FR, Doms RW. A seven-transmembrane domain receptor involved in fusion and entry of T-cell-tropic human immunodeficiency virus type 1 strains. J Virol 1996;70:6288-95.

[43] Combadiere C, Ahuja SK, Tiffany HL, Murphy PM. Cloning and functional expression of CC CKR5, a human monocyte CC chemokine receptor selective for MIP-1(alpha), MIP-1(beta), and RANTES. J Leukocyte Biol 1996;60:147-52.

[44] Samson M, Labbe O, Mollereau C, Vassart G, Parmentier M. Molecular cloning and functional expression of a new human CCchemokine receptor gene. Biochemistry 1996;35:3362-7.

[45] Choe H, Farzan M, Sun Y, Sullivan N, Rollins B, Ponath PD, et al. The $\beta$-chemokine receptors CCR3 and CCR5 facilitate infection by primary HIV-1 isolates. Cell 1996;85:1135-48. 
[46] Bleul CC, Farzan M, Choe H, Parolin C, Clark-Lewis I, Sodroski J, et al. The lymphocyte chemoattractant SDF-1 is a ligand for LESTR/ fusin and blocks HIV-1 entry. Nature 1996;382:829-33.

[47] Oberlin E, Amara A, Bachelerie F, Bessia C, Virelizier JL, ArenzanaSeisdedos F, et al. The CXC chemokine SDF-1 is the ligand for LESTR/fusin and prevents infection by T-cell-line-adapted HIV-1. Nature 1996;382:833-5.

[48] Sattentau QJ. HIV gp120: double lock strategy foils host defences. Structure 1998;6:945-9.

[49] Geijtenbeek TB, Kwon DS, Torensma R, van Vliet SJ, van Duijnhoven GC, Middel J, et al. DC-SIGN, a dendritic cell-specific HIV-1binding protein that enhances trans-infection of $\mathrm{T}$ cells. Cell 2000;100:587-97.

[50] Turville SG, Arthos J, Donald KM, Lynch G, Naif H, Clark G, et al. HIV gp120 receptors on human dendritic cells. Blood 2001;98:2482-8.

[51] Trkola A, Dragic T, Arthos J, Binley JM, Olson WC, Allaway GP, et al. CD4-dependent, antibody-sensitive interactions between HIV-1 and its co-receptor CCR-5. Nature 1996;384:184-7.

[52] Wu L, Gerard NP, Wyatt R, Choe H, Parolin C, Ruffing N, et al. CD4induced interaction of primary HIV-1 gp120 glycoproteins with the chemokine receptor CCR-5. Nature 1996;384:179-83.

[53] Hoffman TL, LaBranche CC, Zhang W, Canziani G, Robinson J, Chaiken I, et al. Stable exposure of the coreceptor-binding site in a CD4-independent HIV-1 envelope protein. Proc Natl Acad Sci USA 1999;96:6359-64.

[54] Cocchi F, DeVico AL, Garzino-Demo A, Cara A, Gallo RC, Lusso P. The V3 domain of the HIV-1 gp120 envelope glycoprotein is critical for chemokine-mediated blockade of infection. Nat Med 1996;2:1244-7.

[55] Weissenhorn W, Dessen A, Harrison SC, Skehel JJ, Wiley DC. Atomic structure of the ectodomain from HIV-1 gp41. Nature 1997;387:426-30.

[56] Barbouche R, Miquelis R, Jones IM, Fenouillet E. Protein-disulfide isomerase-mediated reduction of two disulfide bonds of HIV envelope glycoprotein 120 occurs post-CXCR4 binding and is required for fusion. J Biol Chem 2003;278:3131-6.

[57] Doms RW. Beyond receptor expression: the influence of receptor conformation, density, and affinity in HIV-1 infection. Virology 2000;276:229-37.

[58] Stent G, Joo GB, Kierulf P, Asjo B. Macrophage tropism: fact or fiction? J Leukocyte Biol 1997;62:4-11.

[59] Yi Y, Isaacs SN, Williams DA, Frank I, Schols D, De Clercq E, et al. Role of CXCR4 in cell-cell fusion and infection of monocyte-derived macrophages by primary human immunodeficiency virus type 1 (HIV-1) strains: two distinct mechanisms of HIV-1 dual tropism. J Virol 1999;73:7117-25.

[60] Kristiansen TB, Knudsen TB, Eugen-Olsen J. Chemokine receptors and their crucial role in human immunodeficiency virus infection: major breakthroughs in HIV research. Scand J Immunol 1998;48:339-46.

[61] De Clercq E, Schols D. Inhibition of HIV infection by CXCR4 and CCR5 chemokine receptor antagonists. Antiviral Chem Chemother 2001;12:19-31.

[62] Jekle A, Schramm B, Jayakumar P, Trautner V, Schols D, De Clercq $\mathrm{E}$, et al. Coreceptor phenotype of natural human immunodeficiency virus with nef deleted evolves in vivo, leading to increased virulence. J Virol 2002;76:6966-73.

[63] Jekle A, Keppler OT, De Clercq E, Schols D, Weinstein M, Goldsmith MA. In vivo evolution of human immunodeficiency virus type 1 toward increased pathogenicity through CXCR4-mediated killing of uninfected CD4 T cells. J Virol 2003;77:5846-54.

[64] Penn ML, Grivel JC, Schramm B, Goldsmith MA, Margolis L. CXCR4 utilization is sufficient to trigger $\mathrm{CD} 4^{+} \mathrm{T}$ cell depletion in HIV-1-infected human lymphoid tissue. Proc Natl Acad Sci USA 1999;96:663-8.

[65] Scarlatti G, Tresoldi E, Bjorndal A, Fredriksson R, Colognesi C, Deng HK, et al. In vivo evolution of HIV-1 co-receptor usage and sensitivity to chemokine-mediated suppression. Nat Med 1997;3: 1259-65.

[66] Mellors JW, Rinaldo Jr CR, Gupta P, White RM, Todd JA, Kingsley LA. Prognosis in HIV-1 infection predicted by the quantity of virus in plasma. Science 1996;272:1167-70.

[67] Henrard DR, Daar E, Farzadegan H, Clark SJ, Phillips J, Shaw GM, et al. Virologic and immunologic characterization of symptomatic and asymptomatic primary HIV-1 infection. J Acquir Immune Defic Syndr Hum Retrovirol 1995;9:305-10.

[68] Ho DD, Neumann AU, Perelson AS, Chen W, Leonard JM, Markowitz M. Rapid turnover of plasma virions and CD4 lymphocytes in HIV-1 infection. Nature 1995;373:123-6.

[69] Connor RI, Sheridan KE, Ceradini D, Choe S, Landau NR. Change in coreceptor use coreceptor use correlates with disease progression in HIV-1-infected individuals. J Exp Med 1997;185:621-8.

[70] Este JA, Cabrera C, Blanco J, Gutierrez A, Bridger G, Henson G, et al. Shift of clinical human immunodeficiency virus type 1 isolates from X4 to R5 and prevention of emergence of the syncytiuminducing phenotype by blockade of CXCR4. J Virol 1999;73:5577-85.

[71] Glushakova S, Yi Y, Grivel JC, Singh A, Schols D, De Clercq E, et al. Preferential coreceptor utilization and cytopathicity by dual-tropic HIV-1 in human lymphoid tissue ex vivo. J Clin Invest 1999;104:R711.

[72] Schuitemaker H, Koot M, Kootstra NA, Dercksen MW, de Goede RE, van Steenwijk RP, et al. Biological phenotype of human immunodeficiency virus type 1 clones at different stages of infection: progression of disease is associated with a shift from monocytotropic to T-cell-tropic virus population. J Virol 1992;66:1354-60.

[73] Fouchier RA, Groenink M, Kootstra NA, Tersmette M, Huisman HG, Miedema F, et al. Phenotype-associated sequence variation in the third variable domain of the human immunodeficiency virus type 1 gp120 molecule. J Virol 1992;66:3183-7.

[74] Fouchier RA, Brouwer M, Broersen SM, Schuitemaker H. Simple determination of human immunodeficiency virus type 1 syncytiuminducing V3 genotype by PCR. J Clin Microbiol 1995;33:906-11.

[75] Jensen MA, 't Wout AB. Predicting HIV-1 coreceptor usage with sequence analysis. AIDS Rev 2003;5:104-12.

[76] Bjorndal A, Deng H, Jansson M, Fiore JR, Colognesi C, Karlsson A, et al. Coreceptor usage of primary human immunodeficiency virus type 1 isolates varies according to biological phenotype. J Virol 1997;71:7478-87.

[77] Lin G, Baribaud F, Romano J, Doms RW, Hoxie JA. Identification of gp120 binding sites on CXCR4 by using CD4-independent human immunodeficiency virus type 2 Env proteins. J Virol 2003;77:931-42.

[78] Hu QX, Barry AP, Wang ZX, Connolly SM, Peiper SC, Greenberg $\mathrm{ML}$. Evolution of the human immunodeficiency virus type 1 envelope during infection reveals molecular corollaries of specificity for coreceptor utilization and AIDS pathogenesis. J Virol 2000;74: $11858-72$.

[79] Amara A, Gall SL, Schwartz O, Salamero J, Montes M, Loetscher P, et al. HIV coreceptor downregulation as antiviral principle: SDF1alpha-dependent internalization of the chemokine receptor CXCR4 contributes to inhibition of HIV replication. J Exp Med 1997;186:139-46.

[80] Mack M, Luckow B, Nelson PJ, Cihak J, Simmons G, Clapham PR, et al. Aminooxypentane-RANTES induces CCR5 internalization but inhibits recycling: a novel inhibitory mechanism of HIV infectivity. J Exp Med 1998;187:1215-24.

[81] Marechal V, Arenzana-Seisdedos F, Heard JM, Schwartz O. Opposite effects of SDF-1 on human immunodeficiency virus type 1 replication. J Virol 1999;73:3608-15.

[82] Garzino-Demo A, DeVico AL, Cocchi F, Gallo RC. $\beta$-chemokines and protection from HIV type 1 disease. AIDS Res Hum Retrovir 1998;14:S177-84.

[83] Paxton WA, Martin SR, Tse D, O'Brien TR, Skurnick J, VanDevanter $\mathrm{NL}$, et al. Relative resistance to HIV-1 infection of CD4 lymphocytes 
from persons who remain uninfected despite multiple high-risk sexual exposure. Nat Med 1996;2:412-7.

[84] Gordon CJ, Muesing MA, Proudfoot AE, Power CA, Moore JP, Trkola A. Enhancement of human immunodeficiency virus type 1 infection by the CC-chemokine RANTES is independent of the mechanism of virus-cell fusion. J Virol 1999;73:684-94.

[85] Kelly MD, Naif HM, Adams SL, Cunningham AL, Lloyd AR. Dichotomous effects of beta-chemokines on HIV replication in monocytes and monocyte-derived macrophages. J Immunol 1998;160:3091-5.

[86] Marozsan AJ, Torre VS, Johnson M, Ball SC, Cross JV, Templeton DJ, et al. Mechanisms involved in stimulation of human immunodeficiency virus type 1 replication by aminooxypentane RANTES. J Virol 2001;75:8624-38.

[87] Mosier DE, Picchio GR, Gulizia RJ, Sabbe R, Poignard P, Picard L, et al. Highly potent RANTES analogues either prevent CCR5-using human immunodeficiency virus type 1 infection in vivo or rapidly select for CXCR4-using variants. J Virol 1999;73:3544-50.

[88] Trkola A, Gordon C, Matthews J, Maxwell E, Ketas T, Czaplewski L, et al. The CC-chemokine RANTES increases the attachment of human immunodeficiency virus type 1 to target cells via glycosaminoglycans and also activates a signal transduction pathway that enhances viral infectivity. J Virol 1999;73:6370-9.

[89] Garred P, Eugen-Olsen J, Iversen AK, Benfield TL, Svejgaard A, Hofmann B. Dual effect of CCR5 $\Delta 32$ gene deletion in HIV-1infected patients. Copenhagen AIDS Study Group. Lancet 1997;349: 1884.

[90] Michael NL, Nelson JA, KewalRamani VN, Chang G, O’Brien SJ, Mascola JR, et al. Exclusive and persistent use of the entry coreceptor CXCR4 by human immunodeficiency virus type 1 from a subject homozygous for CCR5 $\Delta 32$. J Virol 1998;72:6040-7.

[91] Gonzalez E, Kulkarni H, Bolivar H, Mangano A, Sanchez R, Catano $\mathrm{G}$, et al. The influence of CCL3L1 gene-containing segmental duplications on HIV-1/AIDS susceptibility. Science 2005;307: 1434-40.

[92] Ma Q, Jones D, Borghesani PR, Segal RA, Nagasawa T, Kishimoto T, et al. Impaired B-lymphopoiesis, myelopoiesis, and derailed cerebellar neuron migration in CXCR4- and SDF-1-deficient mice. Proc Natl Acad Sci USA 1998;95:9448-53.

[93] Nagasawa T, Hirota S, Tachibana K, Takakura N, Nishikawa S, Kitamura Y, et al. Defects of B-cell lymphopoiesis and bone-marrow myelopoiesis in mice lacking the CXC chemokine PBSF/SDF-1. Nature 1996;382:635-8.

[94] Zou YR, Kottmann AH, Kuroda M, Taniuchi I, Littman DR. Function of the chemokine receptor CXCR4 in haematopoiesis and in cerebellar development. Nature 1998;393:595-9.

[95] Menten P, Struyf S, Schutyser E, Wuyts A, De Clercq E, Schols D, et al. The LD78 $\beta$ isoform of MIP-1 $\alpha$ is the most potent CCR5 agonist and HIV-1-inhibiting chemokine. J Clin Invest 1999;104:R1-5.

[96] Aquaro S, Menten P, Struyf S, Proost P, Van Damme J, De Clercq E, et al. The LD78 $\beta$ isoform of MIP- $1 \alpha$ is the most potent CCchemokine in inhibiting CCR5-dependent human immunodeficiency virus type 1 replication in human macrophages. J Virol 2001;75: 4402-6.

[97] De Meester I, Korom S, Van Damme J, Scharpe S. CD26, let it cut or cut it down. Immunol Today 1999;20:367-75.

[98] Schols D, Proost P, Struyf S, Wuyts A, De MI, Scharpe S, et al. CD26processed RANTES(3-68), but not intact RANTES, has potent antiHIV-1 activity. Antiviral Res 1998;39:175-87.

[99] Proost P, De MI, Schols D, Struyf S, Lambeir AM, Wuyts A, et al. Amino-terminal truncation of chemokines by CD26/dipeptidyl-peptidase. IV. Conversion of RANTES into a potent inhibitor of monocyte chemotaxis and HIV-1-infection. J Biol Chem 1998;273: 7222-7.

[100] Arenzana-Seisdedos F, Virelizier JL, Rousset D, Clark-Lewis I, Loetscher P, Moser B, et al. HIV blocked by chemokine antagonist. Nature 1996;383:400.
[101] Simmons G, Clapham PR, Picard L, Offord RE, Rosenkilde MM, Schwartz TW, et al. Potent inhibition of HIV-1 infectivity in macrophages and lymphocytes by a novel CCR5 antagonist. Science 1997;276:276-9.

[102] Proudfoot AE, Power CA, Hoogewerf AJ, Montjovent MO, Borlat F, Offord RE, et al. Extension of recombinant human RANTES by the retention of the initiating methionine produces a potent antagonist. J Biol Chem 1996;271:2599-603.

[103] Lederman MM, Veazey RS, Offord R, Mosier DE, Dufour J, Mefford $\mathrm{M}$, et al. Prevention of vaginal SHIV transmission in rhesus macaques through inhibition of CCR5. Science 2004;306:485-7.

[104] Townson JR, Graham GJ, Landau NR, Rasala B, Nibbs RJ. Aminooxypentane addition to the chemokine macrophage inflammatory protein-1alpha $\mathrm{P}$ increases receptor affinities and HIV inhibition. J Biol Chem 2000;275:39254-61.

[105] Yang OO, Swanberg SL, Lu Z, Dziejman M, McCoy J, Luster AD, et al. Enhanced inhibition of human immunodeficiency virus type 1 by Met-stromal-derived factor 1beta correlates with down-modulation of CXCR4. J Virol 1999;73:4582-9.

[106] De Clercq E, Yamamoto N, Pauwels R, Baba M, Schols D, Nakashima $\mathrm{H}$, et al. Potent and selective inhibition of human immunodeficiency virus (HIV)-1 and HIV-2 replication by a class of bicyclams interacting with a viral uncoating event. Proc Natl Acad Sci USA 1992;89:5286-90.

[107] De Clercq E. The bicyclam AMD3100 story. Nat Rev Drug Discov 2003;2:581-7.

[108] De Clercq E, Yamamoto N, Pauwels R, Balzarini J, Witvrouw M, De Vreese K, et al. Highly potent and selective inhibition of human immunodeficiency virus by the bicyclam derivative JM3100. Antimicrob Agents Chemother 1994;38:668-74.

[109] Bridger GJ, Skerlj RT, Thornton D, Padmanabhan S, Martellucci SA, Henson GW, et al. Synthesis and structure-activity relationships of phenylenebis(methylene)-linked bis-tetraazamacrocycles that inhibit HIV replication. Effects of macrocyclic ring size and substituents on the aromatic linker. J Med Chem 1995;38:366-78.

[110] Joao HC, De Vreese K, Pauwels R, De Clercq E, Henson GW, Bridger GJ. Quantitative structural activity relationship study of bistetraazacyclic compounds. A novel series of HIV-1 and HIV-2 inhibitors. J Med Chem 1995;38:3865-73.

[111] De Vreese K, Kofler-Mongold V, Leutgeb C, Weber V, Vermeire K, Schacht S, et al. The molecular target of bicyclams, potent inhibitors of human immunodeficiency virus replication. J Virol 1996;70:68996.

[112] De Vreese K, Van NI, Vermeire K, Anne J, De Clercq E. Sensitivity of human immunodeficiency virus to bicyclam derivatives is influenced by the three-dimensional structure of gp120. Antimicrob Agents Chemother 1997;41:2616-20.

[113] Este JA, De Vreese K, Witvrouw M, Schmit JC, VanDamme AM, Anne J, et al. Antiviral activity of the bicyclam derivative JM3100 against drug-resistant strains of human immunodeficiency virus type 1. Antiviral Res 1996;29:297-307.

[114] Schols D, Este JA, Henson G, De Clercq E. Bicyclams, a class of potent anti-HIV agents, are targeted at the HIV coreceptor fusin/ CXCR-4. Antiviral Res 1997;35:147-56.

[115] Schols D, Struyf S, Van Damme J, Este JA, Henson G, De Clercq E. Inhibition of T-tropic HIV strains by selective antagonization of the chemokine receptor CXCR4. J Exp Med 1997;186:1383-8.

[116] Donzella GA, Schols D, Lin SW, Este JA, Nagashima KA, Maddon PJ, et al. AMD3100, a small molecule inhibitor of HIV-1 entry via the CXCR4 co-receptor. Nat Med 1998;4:72-7.

[117] Schramm B, Penn ML, Speck RF, Chan SY, De Clercq E, Schols D, et al. Viral entry through CXCR4 is a pathogenic factor and therapeutic target in human immunodeficiency virus type 1 disease. J Virol 2000;74:184-92.

[118] Hatse S, Princen K, Bridger G, De Clercq E, Schols D. Chemokine receptor inhibition by AMD3100 is strictly confined to CXCR4. FEBS Lett 2002;527:255-62. 
[119] Hendrix CW, Flexner C, MacFarland RT, Giandomenico C, Fuchs EJ, Redpath E, et al. Pharmacokinetics and safety of AMD-3100, a novel antagonist of the CXCR-4 chemokine receptor, in human volunteers. Antimicrob Agents Chemother 2000;44:1667-73.

[120] Hendrix CW, Collier AC, Lederman MM, Schols D, Pollard RB, Brown S, et al. Safety, pharmacokinetics, and antiviral activity of AMD3100, a selective CXCR4 receptor inhibitor, in HIV-1 infection. J Acquir Immune Defic Syndr 2004;37:1253-62.

[121] Murakami T, Nakajima T, Koyanagi Y, Tachibana K, Fujii N, Tamamura H, et al. A small molecule CXCR4 inhibitor that blocks T cell line-tropic HIV-1 infection. J Exp Med 1997;186:1389-93.

[122] Arakaki R, Tamamura H, Premanathan M, Kanbara K, Ramanan S, Mochizuki K, et al. T134, a small-molecule CXCR4 inhibitor, has no cross-drug resistance with AMD3100, a CXCR4 antagonist with a different structure. J Virol 1999;73:1719-23.

[123] Tamamura H, Xu Y, Hattori T, Zhang X, Arakaki R, Kanbara K, et al. A low-molecular-weight inhibitor against the chemokine receptor CXCR4: a strong anti-HIV peptide T140. Biochem Biophys Res Com 1998;253:877-82.

[124] Doranz BJ, Grovit-Ferbas K, Sharron MP, Mao SH, Goetz MB, Daar ES, et al. A small-molecule inhibitor directed against the chemokine receptor CXCR4 prevents its use as an HIV-1 coreceptor. J Exp Med 1997;186:1395-400.

[125] Sumner-Smith M, Zheng Y, Zhang YP, Twist EM, Climie SC. Antiherpetic activities of $N$-alpha-acetyl-nona-D-arginine amide acetate. Drugs Exp Clin Res 1995;21:1-6.

[126] Doranz BJ, Filion LG, Diaz-Mitoma F, Sitar DS, Sahai J, Baribaud F, et al. Safe use of the CXCR4 inhibitor ALX40-4C in humans. AIDS Res Hum Retrovir 2001;17:475-86.

[127] Zhou N, Fang J, Acheampong E, Mukhtar M, Pomerantz RJ. Binding of ALX40-4C to APJ, a CNS-based receptor, inhibits its utilization as a co-receptor by HIV-1. Virology 2003;312:196-203.

[128] Daelemans D, Schols D, Witvrouw M, Pannecouque C, Hatse S, van Dooren S, et al. A second target for the peptoid Tat/transactivation response element inhibitor CGP64222: inhibition of human immunodeficiency virus replication by blocking CXC-chemokine receptor 4-mediated virus entry. Mol Pharmacol 2000;57:116-24.

[129] Hamy F, Felder ER, Heizmann G, Lazdins J, Aboul-ela F, Varani G, et al. An inhibitor of the Tat/TAR RNA interaction that effectively suppresses HIV-1 replication. Proc Natl Acad Sci USA 1997;94:3548-53.

[130] Ichiyama K, Yokoyama-Kumakura S, Tanaka Y, Tanaka R, Hirose K, Bannai K, et al. A duodenally absorbable CXC chemokine receptor 4 antagonist, KRH-1636, exhibits a potent and selective anti-HIV-1 activity. Proc Natl Acad Sci USA 2003;100:4185-90.

[131] Schols D, Claes S, Hatse S, Princen K, Vermeire K, De Clercq E, et al. Anti-HIV activity profile of AMD070, an orally bioavailable CXCR4 antagonist. In: Proceedings of the 10th conference on retroviruses and opportunistic infections; 2003 [Abstract book, p. 257].

[132] Princen K, Hatse S, Vermeire K, Aquaro S, De Clercq E, Gerlach LO, et al. Inhibition of human immunodeficiency virus replication by a dual CCR5/CXCR4 antagonist. J Virol 2004;78:12996-3006.

[133] Baba M, Nishimura O, Kanzaki N, Okamoto M, Sawada H, Iizawa Y, et al. A small-molecule, nonpeptide CCR5 antagonist with highly potent and selective anti-HIV-1 activity. Proc Natl Acad Sci USA 1999;96:5698-703.

[134] Dragic T, Trkola A, Thompson DA, Cormier EG, Kajumo FA, Maxwell E, et al. A binding pocket for a small molecule inhibitor of HIV-1 entry within the transmembrane helices of CCR5. Proc Natl Acad Sci USA 2000;97:5639-44.

[135] Strizki JM, Xu S, Wagner NE, Wojcik L, Liu J, Hou Y, et al. SCH-C (SCH 351125), an orally bioavailable, small molecule antagonist of the chemokine receptor CCR5, is a potent inhibitor of HIV-1 infection in vitro and in vivo. Proc Natl Acad Sci USA 2001;98:12718-23.

[136] Reynes J, Rouzier R, Kanouni T, Baillat V, Baroudy B, Keung A, et al. SCH C: Safety and antiviral effects of a CCR5 receptor antagonist in HIV-1 infected subjects. In: Proceedings of the Ninth conference on retroviruses and opportunistic infections; 2002 [Abstract book, p. 53].

[137] Schurmann D, Rouzier R, Nougarede R, Reynes J, Fatkenheuer G, Raffi F, et al. SCH-D: Antiviral activity of CCR5 receptor antagonist. In: Proceedings of the 11th conference on retroviruses and opportunistic infections; 2004 [Abstract book, p. 128].

[138] Maeda K, Yoshimura K, Shibayama S, Habashita H, Tada H, Sagawa K, et al. Novel low molecular weight spirodiketopiperazine derivatives potently inhibit R5 HIV-1 infection through their antagonistic effects on CCR5. J Biol Chem 2001;276:35194200.

[139] Maeda K, Nakata H, Miyakawa T, Ogata H, Koh Y, Shibayama S, et al. AK602: a novel HIV-specific spirodiketopiperazine CCR5 inhibitor potent against a wide spectrum of R5-HIV. In: Proceedings of the 10th conference on retroviruses and opportunistic infections; 2003 [Abstract book, p. 61].

[140] Napier C, Dorr P, Gladue R, Halliday R, Leishman D, Machin I, et al. The preclinical pharmacokinetics and safety pharmacology of the anti-HIV CCR5 antagonist, UK-427857. In: Proceedings of the 10th conference on retroviruses and opportunistic infections; 2003 [Abstract book, p. 251].

[141] Trkola A, Ketas TJ, Nagashima KA, Zhao L, Cilliers T, Morris L, et al. Potent, broad-spectrum inhibition of human immunodeficiency virus type 1 by the CCR5 monoclonal antibody PRO 140. J Virol 2001;75:579-88.

[142] Franti M, Ramos L, Maloveste S, Geerdes D, Nagashima KA, Ketas $\mathrm{T}$, et al. Control of HIV-1 replication in the hu-PBL-SCID mouse model by an anti-CCR5 monoclonal antibody. In: Proceedings of the 11 th conference on retroviruses and opportunistic infections; 2004 [Abstract book, p. 257].

[143] Schols D, Claes S, De Clercq E, Hendrix C, Bridger G, Calandra G, et al. AMD-3100, a CXCR4 antagonist, reduced HIV viral load and X4 virus levels in humans. In: Proceedings of the 9th conference on retroviruses and opportunistic infections; 2002 [Abstract book, p. 53].

[144] Nakata H, Maeda K, Kawano Y, Miyakawa T, Shibayama S, Matsuo $\mathrm{M}$, et al. Potent in vivo anti-R5-HIV effects of AK602, a novel spirodiketopiperazine (SDP)-containing HIV-specific CCR5 inhibitor, in hu-PBMC-NOD-SCID Mice. In: Proceedings of the 10th conference on retroviruses and opportunistic infections; 2003 [Abstract book, p. 258].

[145] Doranz BJ, Rucker J, Yi Y, Smyth RJ, Samson M, Peiper SC, et al. A dual-tropic primary HIV-1 isolate that uses fusin and the betachemokine receptors CKR-5, CKR-3, and CKR-2b as fusion cofactors. Cell 1996;85:1149-58.

[146] Jinno A, Shimizu N, Soda Y, Haraguchi Y, Kitamura T, Hoshino H. Identification of the chemokine receptor TER1/CCR8 expressed in brain-derived cells and $\mathrm{T}$ cells as a new coreceptor for HIV-1 infection. Biochem Biophys Res Commun 1998;243:497502.

[147] Horuk R, Hesselgesser J, Zhou Y, Faulds D, Halks-Miller M, Harvey S, et al. The CC chemokine I-309 inhibits CCR8-dependent infection by diverse HIV-1 strains. J Biol Chem 1998;273: 386-91.

[148] Choe H, Farzan M, Konkel M, Martin K, Sun Y, Marcon L, et al. The orphan seven-transmembrane receptor apj supports the entry of primary T-cell-line-tropic and dualtropic human immunodeficiency virus type 1. J Virol 1998;72:6113-8.

[149] Combadiere C, Salzwedel K, Smith ED, Tiffany HL, Berger EA, Murphy PM. Identification of CX3CR1. A chemotactic receptor for the human $\mathrm{CX} 3 \mathrm{C}$ chemokine fractalkine and a fusion coreceptor for HIV-1. J Biol Chem 1998;273:23799-804.

[150] Liao F, Alkhatib G, Peden KW, Sharma G, Berger EA, Farber JM. STRL33, a novel chemokine receptor-like protein, functions as a fusion cofactor for both macrophage-tropic and $\mathrm{T}$ cell line-tropic HIV-1. J Exp Med 1997;185:2015-23. 
[151] Matloubian M, David A, Engel S, Ryan JE, Cyster JG. A transmembrane CXC chemokine is a ligand for HIV-coreceptor Bonzo. Nat Immunol 2000;1:298-304.

[152] Edinger AL, Hoffman TL, Sharron M, Lee B, Yi Y, Choe W, et al. An orphan seven-transmembrane domain receptor expressed widely in the brain functions as a coreceptor for human immunodeficiency virus type 1 and simian immunodeficiency virus. J Virol 1998;72: 7934-40.
[153] Deng HK, Unutmaz D, KewalRamani VN, Littman DR. Expression cloning of new receptors used by simian and human immunodeficiency viruses. Nature 1997;388:296-300.

[154] Heiber M, Marchese A, Nguyen T, Heng HH, George SR, O'Dowd BF. A novel human gene encoding a G-protein-coupled receptor (GPR15) is located on chromosome 3. Genomics 1996;32: $462-5$. 